\title{
Terminal Pleistocene-Holocene avifauna of San Miguel and Santa Rosa Islands: identifications of previously unidentified avian remains recovered from fossil sites and prehistoric cave deposits
}

\author{
Paul W. Collins ${ }^{1}{ }^{*}$, Daniel A. Guthrie ${ }^{2}$, Emily L. Whistler ${ }^{3}$, \\ René L. Vellanoweth ${ }^{4}$, AND Jon M. ERLandson 5 \\ ${ }^{1}$ Santa Barbara Museum of Natural History, 2559 Puesta Del Sol, Santa Barbara, CA 93105 \\ 2264 Blaisdell Dr., Claremont, CA 91711 \\ ${ }^{3}$ Department of Anthropology, Box 644910, Washington State University, Pullman, WA 99163 \\ ${ }^{4}$ Department of Anthropology, California State University, Los Angeles, \\ 5151 State University Drive, Los Angeles, CA 90032-8220 \\ ${ }^{5}$ Museum of Natural and Cultural History, University of Oregon, Eugene, OR 97403-1224
}

\begin{abstract}
We provide an update to the fossil avifauna of San Miguel and Santa Rosa Islands based on the identification of 3509 small bird bones recovered from fossil sites on Santa Rosa and from 3 archaeological-paleontological cave deposits and 20 fossil sites on San Miguel. This work adds 64 species to the fossil avian community of these 2 islands, increasing the previous total from 83 to 147 species, making this the richest Late Pleistocene-Holocene coastal avifaunal assemblage recorded for California. Of the 64 newly identified species, 62 are new additions to the Channel Islands fossil avifauna and 40 are new to the fossil avifauna of California. Twenty-two species were confirmed to have nested on San Miguel Island during the Holocene based on the identification of juvenile/immature bones. At least 4 land birds (Burrowing Owl [Athene cunicularia], Island Scrub-Jay [Aphelocoma insularis], Bewick's Wren [Thryomanes bewickii], and Spotted Towhee [Pipilo maculatus]) that nested prehistorically on San Miguel have disappeared from the modern record there. Island Scrub-Jay bones were identified from 3 fossil sites on San Miguel and 1 site on Santa Rosa, providing the first confirmation that this species lived on both islands during the Pleistocene and Holocene. Island Scrub-Jays disappeared from San Miguel Island sometime in the Late Holocene, but a small population may have lingered on Santa Rosa Island into historic times before dying out. Destruction of island scrub and woodland habitats following the introduction of livestock in the mid-19th century probably caused the extirpation of resident breeding populations of Bewick's Wren and Spotted Towhee from San Miguel Island and Island Scrub-Jay from Santa Rosa Island.
\end{abstract}

Resumen.-Aportamos una actualización al registro de la avifauna fósil de las Islas San Miguel y Santa Rosa con base en la identificación de 3509 huesos de pájaros pequeños recuperados de yacimientos fosilíferos en Santa Rosa, depósitos provenientes de 3 cuevas con contextos arqueológicos-paleontológicos en la Isla de San Miguel y de 20 yacimientos fosilíferos también de San Miguel. Esta obra agrega sesenta y cuatro especies más al registro de la avifauna fósil de estas islas, incrementando el total previo de 83 a 147 especies, haciendo esta efectivamente la colección más rica de avifauna costera del Pleistoceno Superior-Holoceno documentada para el estado de California. De las 64 especies recién documentadas, 62 son nuevas adiciones al registro de la avifauna fósil de las Islas Canal de California y 40 son nuevas al registro de la avifauna fósil del estado de California. Se ha confirmado que 22 especies anidaban en la Isla de San Miguel durante el Holoceno según la identificación de huesos de menores/inmaduros. Cuatro pájaros terrestres como poco (Athene cunicularia, Aphelocoma insularis, Thryomanes bewickii y Pipilo maculatus) que anidaban prehistóricamente en Isla San Miguel han desaparecido del registro moderno de la isla. Huesos de Aphelocoma insularis fueron identificados de 3 yacimientos fosilíferosen en San Miguel y de 1 yacimiento en Santa Rosa, confirmando por primera vez que esta especie vivía en ambas islas durante el Pleistoceno y el Holoceno. Aphelocoma insularis desapareció de la Isla San Miguel durante el Holoceno superior, pero una pequeña población podría haber perdurado en Santa Rosa en tiempos históricos antes de extinguirse. La destrucción de los matorrales de las islas y de los hábitats boscosos, siguiendo la introducción de ganado a mediados del siglo XIX, probablemente provocó la extinción de las poblaciones reproductoras de Thryomanes bewickii y Pipilo maculatus en la Isla San Miguel y de Aphelocoma insularis en la Isla Santa Rosa.

*Corresponding author: pcollins@sbnature2.org 
The fossil avifauna of the Channel Islands has been intensively studied on San Miguel Island (Guthrie 1980, 1985, 1992b, 1993, 1998, 2005, Guthrie et al. 2002), with smaller samples analyzed from Santa Rosa (Howard 1944, 1949, Orr 1968), west Anacapa (Miller et al. 1961, Howard 1964b, Lipps 1964, Guthrie 1985), Santa Barbara (Lipps et al. 1968), and San Nicolas Islands (Howard 1955, Guthrie et al. 2002). Twenty-five species of birds, mostly geese and ducks, have been recorded from Late Pleistocene-Holocene (approximately 37,000 and $\sim 10,000$ RYBP) fluvial deposits found along the northwest side of Santa Rosa Island (Howard 1949, Orr 1968). The majority of the identified avian fossils from Santa Rosa Island are aquatic species (waterfowl and marine birds), with terrestrial birds such as California Condor (Gymnogyps amplus), Redtailed Hawk (Buteo jamaicensis), Crested Caracara (Caracara cheriway $[=$ Polyborus plancus prelutosus]), an extinct eared owl (Asio priscus), and Common Raven (Corvus corax; Orr 1968) also present. Extinct species of the Late Pleistocene avifauna of Santa Rosa Island include a flightless duck (Chendytes lawi), a gannet (Morus reyanus), a condor, a caracara, and an eared owl (Howard 1955, 1962, 1964a, Orr 1968, Erlandson et al. 2011).

The Quaternary avifauna of San Miguel Island has been more thoroughly documented, with 18,840 bird bones identified from 19 fossil localities and 2 cave/rockshelter sites (Guthrie 1980, 1992b, 1993, 1998, 2005, Guthrie et al. 2002). This avifauna was dominated by aquatic species (waterfowl and marine birds), with smaller numbers of terrestrial birds, including scavengers (vultures, caracaras, ravens, and Bald Eagles), predators (hawks, falcons, and owls), and passerine songbirds. This fossil avifauna comprised 83 species, including all the extinct species recorded for Santa Rosa Island along with Late Pleistocene breeding populations of 2 extinct aquatic species (Chendytes lawi and Fratercula dowi; Guthrie et al. 2002, Guthrie 2005) and 1 extant species of auklet (Synthliboramphus antiquus; Guthrie 2005). The most abundant species found in fossil sites studied to date on San Miguel Island included 4 nesting aquatic birds in decreasing order of abundance, an extinct puffin (Fratercula dowi), Cassin's Auklet (Ptychoramphus aleuticus), Ancient Murrelet (Synthliboramphus antiquus), and a flightless duck (Chendytes lawi; Guthrie 2005). Only small numbers of passerine songbird bones have been identified in the fossil record for San Miguel Island, confirming that more work is needed to better document the terrestrial avifauna of the island during the Quaternary.

Besides the birds listed above, there are a variety of other terrestrial animals that are known to have disappeared from San Miguel Island in prehistoric times, including the chorus frog (Pseudacris; Mead et al. 2018), western rattlesnake (Crotalus oreganus), gopher snake (Pituophis catenifer pumilis), ornate shrew (Sorex ornatus), an extinct vampire bat (Desmodus stocki), giant deer mouse (Peromyscus nesodytes), San Miguel Island vole (Microtus miguelensis), spotted skunk (Spilogale gracilis), pygmy mammoth (Mammuthus exilis), and Columbian mammoth (M. columbi; Guthrie 1980, 1993, 1998, Walker 1980, Rick et al. 2012). Most of these extinctions were due to dramatic changes occurring in terrestrial environments on San Miguel Island following the Last Glacial Maximum (LGM), as Santarosae broke apart and lost approximately $75 \%$ of its landmass (Clark et al. 2014, ReederMyers et al. 2015), the climate warmed and became drier, and habitats changed from wet coniferous forests and evergreen woodlands to dryer scrublands and grasslands. Although Native American populations were present on the Channel Islands for at least 13,000 years (Erlandson et al. 2008, 2011), few animals are known to have gone extinct on this archipelago during the prehistoric human era (Rick et al. 2012). Most of the animals listed above that went extinct were unable to adapt quickly enough to changes in climate and habitat during the Late Pleistocene-early Holocene and as a result were driven to extinction prior to the arrival of Europeans and their grazing livestock in the 19th century. Two of these species may have persisted into historic times, becoming extinct after the introduction of herbivores to the island in the 1800s and the vegetation stripping and habitat changes that ensued. In the Early Holocene, deer mice (Peromyscus maniculatus) were probably introduced to the Channel Islands incidentally as stowaways on Native American watercraft (Walker 1980, Guthrie 1993, 1998, Rick et al. 2012). Competition between P. maniculatus and $P$. nesodytes is one factor that may have contributed to the extinction of $P$. nesodytes 
(Rick et al. 2012). Several authors have suggested that $P$. nesodytes may have persisted on San Miguel Island into historic times before becoming extinct following 19th-century vegetation stripping and habitat changes associated with overgrazing by herbivores and severe drought (Walker 1980, Ainis and Vellanoweth 2012). Ornate shrews also have been found in trans-Holocene deposits on San Miguel Island at Daisy Cave (CA-SMI-261 and CA-SMI261A) and Cave of the Chimneys (CA-SMI-603) (Walker 1980, Guthrie 1998, Allen 2013), and may also have persisted into the 19th century (Guthrie 1998). Both of these species may have lived into the historic period on San Miguel, but no bones of either species have been recovered from deposits younger than $\sim 960$ to 1070 cal BP (Ainis and Vellanoweth 2012, Allen 2013), nor are there any recent specimens that confirm their distribution on any of the northern Channel Islands into the historic period. Further work is needed to determine the timing and mechanism of their extirpation.

Until the current study, only 79 small passerine bird bones were identified to genus or species from fossil sites on San Miguel and Santa Rosa Islands. The Common Raven was recorded in a number of sites (Orr 1968, Guthrie 1980, 2005), with 6 additional passerine species recorded for San Miguel based on identification of 62 bones (Guthrie 1980, 2005). Due in part to the difficulty of identifying passerine bone, 223 small land bird bones recovered from Daisy Cave and Cave A by Charles Rozaire in the 1960s were only identified to the order Passeriformes (Guthrie 1980). Since this earlier work, additional samples of small avian remains have been collected from further excavations at Daisy Cave (CASMI-261 and CA-SMI-261A), Cave of the Chimneys (CA-SMI-603), a fossil owl roost (SMI-V-20) along the northwest coast of San Miguel Island, and from 12 fossil sites along the northwest coast of Santa Rosa Island. Detailed study of these fossil land bird bones provides insights into dramatic changes occurring to terrestrial ecosystems on the northern Channel Islands from the Late Pleistocene through the Holocene.

We examined all previously unidentified samples of small avian bone recovered from a series of fossil sites and cave/rockshelter deposits on San Miguel and Santa Rosa Islands to gain a better understanding of the fossil avifauna of the northern Channel Islands and to determine whether anthropogenic impacts following the arrival of Native Americans and later Europeans contributed to the extinction of any resident birds. Our principal goal was to document the fossil land bird fauna by carefully identifying recovered passerine (order Passeriformes) and nonpasserine land bird bones from fossil sites (SMI-V-20, CA-SMI261, CA-SMI-261A, and CA-SMI-603) used intermittently for millennia by Barn Owls (Tyto alba) for roosting or nesting. This fossil land bird fauna was then examined to see how it has been affected through time by millennialor centennial-scale natural (climatic warming and sea level rise) changes and anthropogenic changes that have affected terrestrial ecosystems on the northern Channel Islands, especially since the arrival of Europeans.

\section{Environmental Setting and Paleoecology} of the Northern Channel Islands

San Miguel and Santa Rosa are the westernmost islands in the northern Channel Islands. Today they are situated between 42 and $44 \mathrm{~km}$ off the mainland coast of central California and are $37 \mathrm{~km}^{2}$ (San Miguel) and $217 \mathrm{~km}^{2}$ (Santa Rosa), respectively (McEachern et al. 2016). These islands have never been connected to the adjacent mainland during the Quaternary but were connected to one another several times during low sea stands in the Pleistocene (Muhs et al. 2014, 2015, Reeder-Myers et al. 2015). At the last glacial maximum (LGM, -23-12 ka), when sea levels declined to 95-105 m below present (Reeder-Myers et al. 2015), the northern Channel Islands (San Miguel, Santa Rosa, Santa Cruz, and Anacapa) coalesced to form a single super-island called Santarosae (Orr 1968). This landmass reached its largest size $\left(\sim 2147 \mathrm{~km}^{2}\right)$ about 20,000 years ago, after which it shrank as the climate warmed (Reeder-Myers et al. 2015). By $\sim 11 \mathrm{ka}$ the islands forming Santarosae began separating into the 4 islands that today make up the northern Channel Islands. Anacapa separated first, between $\sim 10,900$ and 10,300 cal BP, followed by Santa Cruz, between $\sim 9900$ and 9400 cal BP, and San Miguel and Santa Rosa, between $\sim 9400$ and 9100 cal BP (ReederMyers et al. 2015). As sea levels rose, Santarosae lost about $75 \%$ of its original landmass (Kennett et al. 2008). During the Late Pleistocene, a broad coastal plain surrounded most 
of San Miguel and Santa Rosa Islands (ReederMyers et al. 2015). Some areas of this exposed coastal plain, particularly along the northwest shore of Santarosae north of present-day San Miguel Island, were covered by active sand dunes (Johnson 1972, Muhs et al. 2009).

During the terminal Pleistocene, between about 17,000 and 13,000 years ago, climate was generally wetter and colder (Heusser 1998, Stott et al. 2002), supporting conifer forests of cypress (Cupressus), pine (Pinus), and Douglasfir (Pseudotsuga) on parts of Santarosae, along with a diverse understory of subshrubs and herbs comparable to habitats found today in coastal northern California (Chaney and Mason 1930, Anderson et al. 2008). Mixed conifer forest also covered highland areas of present-day Santa Rosa Island during the LGM (Anderson et al. 2010). Oak and other woodland plant communities, which today are restricted to protected north-facing slopes and canyon bottoms on Santa Cruz and Santa Rosa Islands, do not appear to have expanded significantly during the last 2 millennia of the Pleistocene (Anderson et al. 2010, Reeder-Myers et al. 2015). However, as climate began to warm in the Late Pleistocene-Early Holocene, the mixed conifer forest was replaced by Bishop pine (Pinus muricata) stands, which according to Reeder-Myers et al. (2015), expanded to lower elevations on Santarosae to cover larger areas of the broad coastal plain. Pinus pollen was common in Late Pleistocene $(<13,000 \mathrm{cal}$ BP) sediments from Arlington Canyon on Santa Rosa (Kennett et al. 2008) and Daisy Cave on eastern San Miguel (West and Erlandson 1994). Pollen data from Soledad Pond on Santa Rosa Island showed that by about 11,800 years ago, as climate warmed and became increasingly drier, pine forests declined and were largely replaced by coastal sage scrub and grassland communities (Cole and Liu 1994, Anderson et al. 2010). Pollen data from Abalone Rocks Marsh on Santa Rosa revealed that a variety of plant communities were present in the vicinity during the Holocene, including coastal sage scrub, grassland, oak grassland, and pine woodland (Anderson et al. 2010). The Early Holocene, particularly between $\sim 9150$ and 6900 years ago, was marked by increasingly drier conditions (Anderson et al. 2010). Pollen records from the nearby Santa Barbara Basin (Heusser 1978, 1995, 1998) and 2 sites along San Antonio Creek in northern Santa Barbara
County (Anderson et al. 2015) recorded a similar shift in climate and plant communities along the adjacent mainland during the Middle to Late Holocene.

Since the LGM, grass-brush fires occurred on the northern Channel Islands throughout the Holocene, based on the sedimentary record from San Miguel Island (Johnson 1972, 1977) and from charcoal records in sediment cores from Soledad Pond and Abalone Rocks Marsh on Santa Rosa (Anderson et al. 2010). An increase of charcoal in sediment cores from Santa Rosa Island and in sedimentary deposits in Arlington Canyon on Santa Rosa Island in the Late Holocene from approximately 3500 years ago into the historic period suggests greater fire frequency, likely due to purposeful or accidental landscape burning of vegetation, first by Native Americans and later by ranchers during the historic period (Anderson et al. 2010, Rick et al. 2014, Hardiman et al. 2016). This prehistoric and historic landscape burning further altered plant communities on the northern Channel Islands-probably expanding the extent of grasslands and forb fields-as human populations increased on the islands through the Late Holocene. However, the most dramatic change to plant communities on the islands came during the historic ranching era (the mid-1800s through the late 1900s), when a variety of domestic herbivores and game species were introduced. During a century of overgrazing and trampling by introduced mammals, island landscapes and ecosystems were dramatically altered by removal of vegetation, serious soil erosion, and widespread dune destabilization (Junak et al. 1995, Reddy and Erlandson 2012, Rick et al. 2014). During historic times, plant communities transitioned from woodlands and extensive areas of native perennial shrublands to extensive areas of nonnative annual grasslands and bare ground. However, as herbivores were removed from the islands during the past 4 decades, native vegetation has increased and scrub, woodland, and wetland plant communities are slowly recovering (McEachern et al. 2016).

Changes occurring on the northern Channel Islands during the terminal PleistoceneHolocene in landmass, terrestrial habitats, and island separation would have had dramatic effects on coastal dune ecosystems, terrestrial plant communities, terrestrial birds, and seabird nesting colonies (Reeder-Myers et al. 


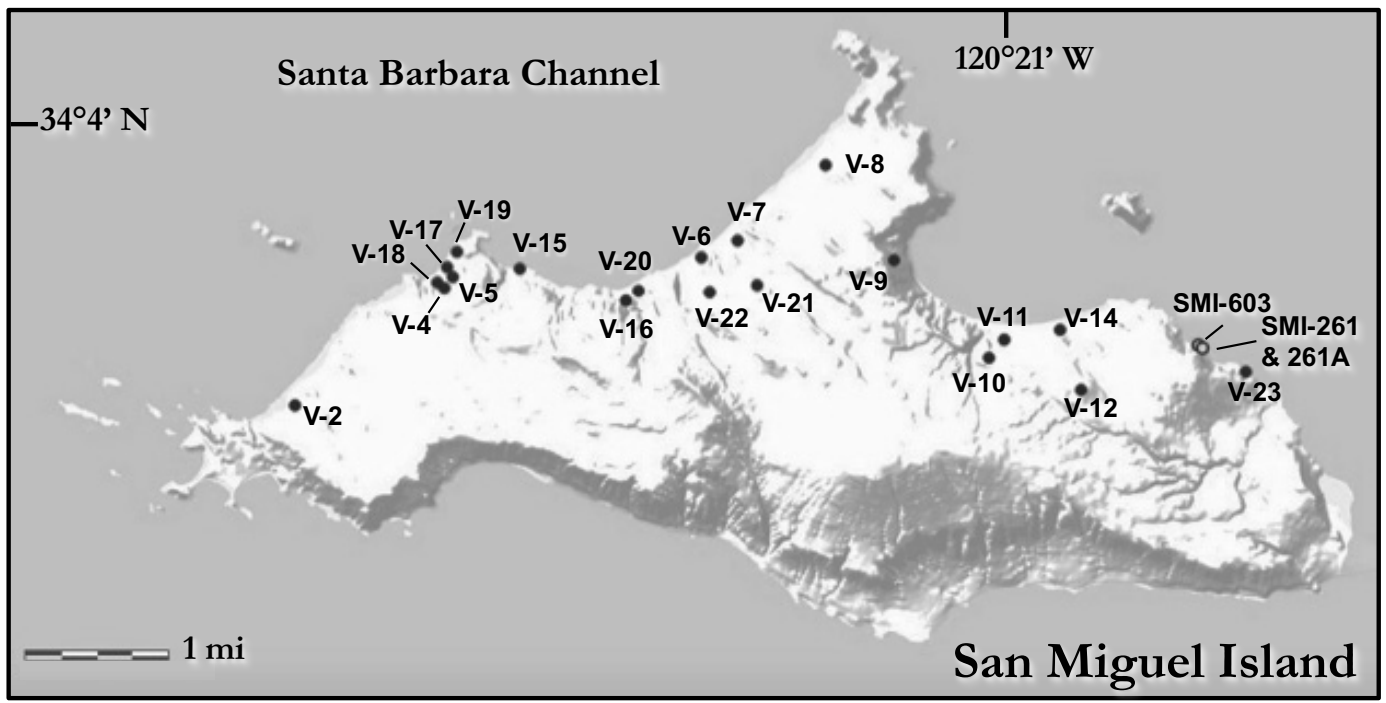

Fig. 1. Map showing the locations of fossil bird localities on San Miguel Island, California. Map was made in ArcGIS by Alexis Mychajliw using the following sources: Esri, USGS, NOAA, Delorme, and NPS.

2015). These environmental changes had significant paleoecological and biogeographical implications. During the LGM, species once confined to one or more of the northern Channel Islands could have disbursed readily across the Santarosae landmass to inhabit land that was inaccessible after the larger island split into 4 separate islands. Terrestrial habitats available to wildlife during the terminal Pleistocene and Holocene were also adjusting as a result of climate change (i.e., cool-wet to warm-dry conditions). As landmasses shrunk and habitats changed, population size for species on the smaller islands like San Miguel and Anacapa would have declined, increasing vulnerability to extinction from habitat loss and stochastic factors that affect small populations. Vegetation stripping due to historic overgrazing also dramatically altered the island's terrestrial plant communities and negatively affected their resident biotas. Dramatic environmental changes of the historic period probably also contributed to the decline and disappearance of a number of resident land birds prior to when ornithologists first began documenting the avifauna of the islands in the late 1800s and early 1900s. Identifications of small land bird and seabird remains recovered from fossil sites and cave deposits on San Miguel and Santa Rosa Islands provide data useful for characterizing the avifauna of the northern Channel Islands during the Holocene prior to historical habitat changes. Identifying extant species of birds among these fossil remains that could have disappeared can also inform land managers about which species should be considered for reintroduction to an island to improve ecosystem functioning. Understanding how this prehistoric avifauna responded to climate and vegetation changes on the northern Channel Islands can also help predict how bird populations on the islands today are likely to respond to habitat changes occurring following the removal of herbivores and the passive recovery of terrestrial plant communities and pending effects of global climate change.

\section{Site Descriptions, Stratigraphy, and Chronology}

Between 1980 and 2002, Guthrie periodically surveyed and salvaged exposed fossil bones eroding out of Pleistocene sediments at 23 sites from the north coast and interior areas on San Miguel Island (Fig. 1). Avian remains recovered from 19 of these fossil locales were previously identified and quantified to describe the fossil avifauna of San Miguel Island (Guthrie 1992b, 1993, 1998, 2005). Guthrie identified approximately 16,860 bones of 61 species of birds from these 19 fossil sites (Guthrie 2005). Fossil remains recovered from SMI-V-20, a prehistoric Barn Owl roost or nest midden that was radiocarbon dated to 7300 RYBP (Guthrie 2005), were not included 
in Guthrie's previous publications on San Miguel Island's fossil avifauna. Unidentified small avian remains and passerine bone from the 19 sites previously analyzed by Guthrie, along with bird bones from SMI-V-20, are identified and included in the current study.

Most of the fossil sites examined by Guthrie on San Miguel Island are of Late Pleistocene age with radiocarbon dates from as recent as $\sim 12,000$ RYBP and as early as $\sim 40,000$ RYBP (Guthrie 1992b, 1993, 2005), with at least one site of Late Holocene age being a superficial palimpsest of fossils and more recent materials. A total of 6 radiocarbon dates were obtained from bone collagen from 5 of Guthrie's fossil localities (sites 4, 7, 10, 12, and 20; Appendix 1; Guthrie 1992b, 1993). In general, these fossils date from 2 periods. The majority of sites were found within a wave-cut bench, and they date between $\sim 25,000$ and $\sim 39,000$ RYBP. Four sites (sites 4,12, 21, and 22) were found inland and above the wave-cut bench, and they date from about 12,000 RYBP (Guthrie 1992b, 1993; Appendix 1). Fossil-bearing sediments on San Miguel Island formed in a variety of ways. First, sites associated with the wave-cut bench along the north shore of the island (sites 8, 14, $15,17,18$, and 19) were formed through the erosion of sea cliffs, with eroded materials being washed to lower levels toward the north shore of the island before being buried by windblown sand (Guthrie 2005). Second, a few sites in the Simonton Cove area (sites 6, 7, 10, and 16) were the result of material eroded from higher levels combining with seabird (alcid) remains from prehistoric breeding sites (Guthrie 2005). These types of sites could date anywhere from the late Pleistocene $\left(\sim 38,000{ }^{14} \mathrm{C}\right.$ yr BP$)$ to the historic period, due to erosion and mixing of bone from nearby archaeological sites and recent biological material into these paleontological deposits (Rick et al. 2009). Third, inland fossil locales (sites 4, 12, 21, and 22) formed, with widely scattered and worn surface fossils being buried by sand blown inland from beaches along the north and northwest coast of the island (Guthrie 2005). Finally, several sites appear to be the result of the accumulation of prey remains at prehistoric Bald Eagle nests (sites 7 and 16) and at a prehistoric Barn Owl roost or nest site (site 20; Guthrie 2005). The absence of any noticeable changes in the composition of the avifauna found in fossil sites on
San Miguel Island, coupled with the lack of noticeable evolutionary changes in this fauna, led Guthrie (1993) to conclude that the fossil deposits should be treated as a single faunal zone of Late Pleistocene age.

On Santa Rosa Island, relatively few avian remains have been collected from fossil localities. Phil Orr collected a total of 167 bird bones from fluvial deposits at a series of Late Pleistocene-Early Holocene-aged sites scattered along the northwest side of Santa Rosa Island. With the help of Hildegard Howard, most of the recovered fossil bird bones were identified and assigned to specific geologic members (Garañon, Fox, or Tecolote) of the Santa Rosa Island Formation (Orr 1968). The Tecolote member is of more recent age, based on a radiocarbon date of 12,500 years $\mathrm{BP}$ (Orr 1956, 1960). Ages originally reported by Orr (1960, 1968) from U-series dating of molluscs for the Garañon and Fox geologic members have recently been shown to be inaccurate. Recent U-series dates obtained on fossil corals recovered from marine facies of both geologic members recorded ages of 80,000 years BP for the Garañon member and 125,000 years BP for the Fox member (Muhs et al. 2014, 2015).

In 1987 and 1991, vertebrate fossils were collected from 12 additional sites along the northwest shore of Santa Rosa Island (Guthrie 1992a). Avian remains were recovered and identified from 9 of these locales (Fig. 2) and are reported for the first time in the current study. Radiocarbon dates were obtained from only 2 of these fossil locales (SRI-V-1 and SRI-V-2), while the remaining 7 locales were assigned to specific geologic members of the Santa Rosa Island Formation (Appendix 1). Dated locales were both from the lower Tecolote Member of the Santa Rosa Island Formation with ${ }^{14} \mathrm{C}$ dates of 39,300 RYBP (Beta-22183) for SRI-V-1 and 10,280 \pm 180 RYBP (Beta-22184) for SRI-V-2 (Appendix 1; Guthrie 1992a). Three of the sites (SRI-V-4, 6, and 8) were from the Pleistocene-aged Garañon member, and 4 sites (SRI-V-3, 10-12) were from the Late Pleistocene-Early Holocene-aged Tecolote Member (Appendix 1, Guthrie 1992a). A site near the mouth of Arlington Canyon (SRI-V-3), containing a concentration of small terrestrial vertebrate bone, represents a long-term owl roost of Late Pleistocene-Early Holocene age (Guthrie 1992a, 1998). 


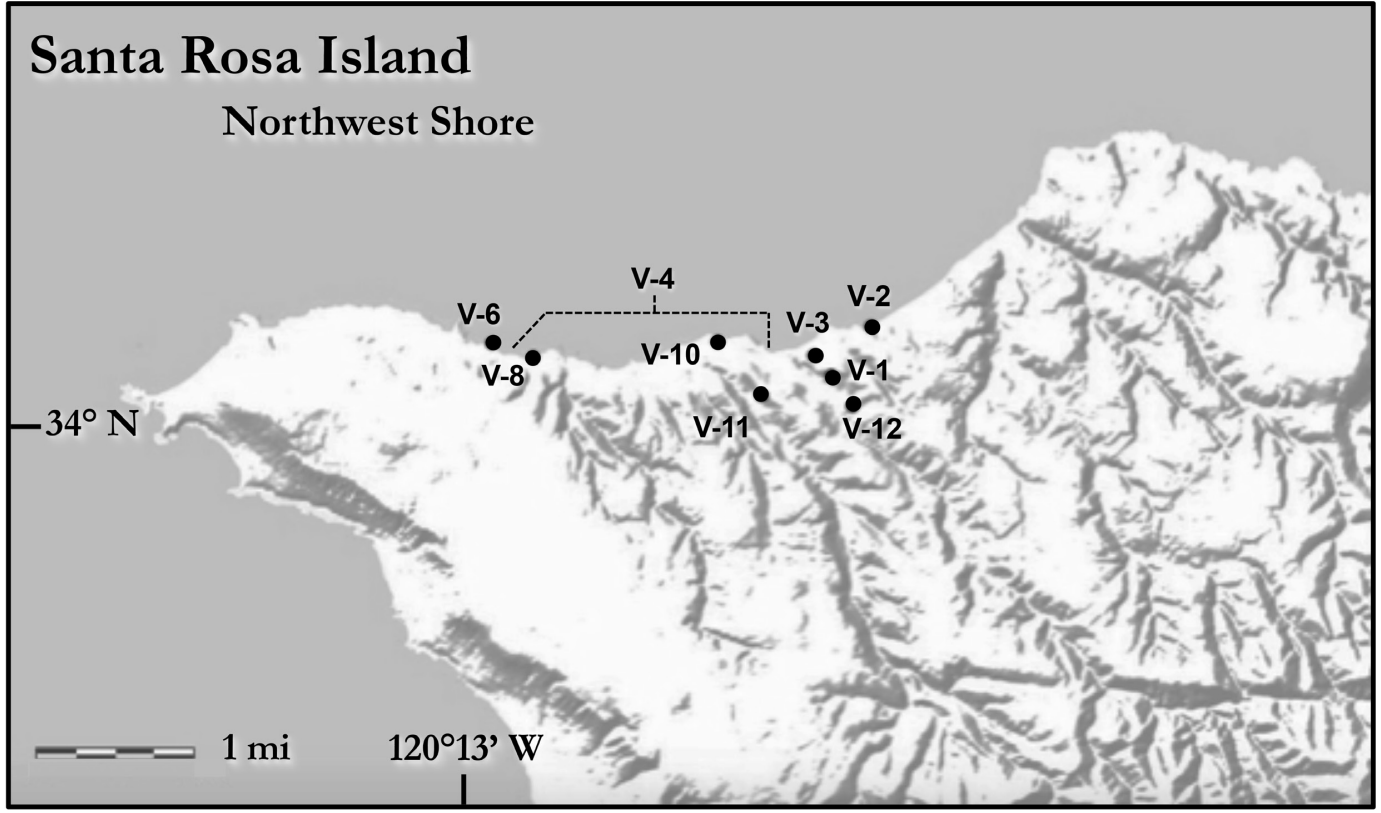

Fig. 2. Map showing the locations of fossil bird localities on the northwest coast of Santa Rosa Island, California. Map was made in ArcGIS by Alexis Mychajliw using the following sources: Esri, USGS, NOAA, Delorme, and NPS.

Bird remains have also been recovered from 2 cave/rockshelter sites from the northeast coast of San Miguel Island (Daisy Cave and Cave of the Chimneys) that contain a combination of archaeological and paleontological materials that result from intermittent use by humans and Barn Owls since the terminal Pleistocene (Fig. 1). Daisy Cave (CA-SMI261), a multicomponent archaeological site (Fig. 1), consists of 2 separate areas, including a narrow fissure cave referred to as Cave A (CA-SMI-261A) that is approximately $11 \mathrm{~m}$ deep and 1.5-3 m wide (Erlandson et al. 1996) and a rockshelter (CA-SMI-261) outside the mouth of Cave A that is about $4 \mathrm{~m}$ long by $5 \mathrm{~m}$ deep with a shell midden on the slope below it (Erlandson et al. 1996, Rick et al. 2001). Multiple excavations have taken place at Daisy Cave, with looters and antiquarians disturbing much of the interior of Cave $\mathrm{A}$ in the late 1800s and early 1900s. Charles Rozaire of the Los Angeles County Museum of Natural History supervised the first well-documented archaeological work of Daisy Cave in 1967-1968 (Rozaire 1978), excavating roughly $20 \%$ of the deposits in a series of $1.52 \times 1.52-\mathrm{m}$ $\left(2.32-\mathrm{m}^{2}\right)$ test pits excavated in arbitrary 6 inch $(15.2-\mathrm{cm})$ levels oriented horizontally
(Rozaire 1978, Erlandson et al. 1996). The arbitrary 6-inch levels excavated in each of Rozaire's test pits at Daisy Cave often crosscut sloping and finely stratified cave sediments, making it difficult to precisely date assemblages from Rozaire's excavations to anything other than general time periods (Erlandson et al. 1996). Samples collected by Rozaire from Daisy Cave span from the terminal Pleistocene through the Late Holocene. Excavated sediments were screened on-site with $1 / 4-$ in $(\sim 6-\mathrm{mm})$ screens, resulting in underrepresentation of small faunal remains.

In 1985-1986, Snethkamp, Guthrie, and Morris excavated 2 small test pits inside Cave A and 2 column samples from Rozaire's trench walls in front of the Daisy Cave rockshelter (CA-SMI-261). Additional ${ }^{14} \mathrm{C}$ dates obtained from samples collected suggested that human occupation of the site spanned nearly 12,000 years (Erlandson et al. 1996). During the 1990s, Erlandson finished the stratigraphically controlled excavation of four $50 \times 100$-cm-wide test units located along the dripline of the rockshelter (Erlandson et al. 1996). Work during the 1990s at Daisy Cave resulted in the collection of larger samples of artifacts, faunal and plant remains, and additional ${ }^{14} \mathrm{C}$ dates 
for Daisy Cave (Erlandson et al. 1996, Rick et al. 2001, Reddy and Erlandson 2012). As a result, more than $60{ }^{14} \mathrm{C}$ dates from Daisy Cave provide a detailed site chronology for interpreting avian faunal assemblages from secure stratigraphic contexts (Appendix 1). Avian remains recovered from 2 small test pits dug in Cave A (Snethkamp samples) and from 1 column sample (Column E-6) in front of the Daisy Cave rockshelter are included in the current study. Column E- 6 was $20 \times 60 \mathrm{~cm}$ wide and $\sim 130 \mathrm{~cm}$ deep, with an estimated total volume of approximately $117 \mathrm{~L}$ (Reddy and Erlandson 2012). Column E-6 provided the first high-resolution stratigraphically controlled column sample collected from Daisy Cave. Nine strata $(\mathrm{A}-\mathrm{I})$ were identified in this column, and $32{ }^{14} \mathrm{C}$ dates anchor a detailed chronology for these strata. These $32{ }^{14} \mathrm{C}$ dates allow for more precise dating of the avian paleontological assemblage recovered from Column E-6, which spans a period from the Terminal Pleistocene through the Holocene $(\sim 13,500-2850$ cal BP). Calibrated ages for each stratum of Column E-6 were as follows: Stratum A, 2850-3700; Stratum B, -3700-6400; Stratum C, 6400-6900; Stratum D, 6900-8500; Stratum E, 8500-9250; Stratum F, 9250-10,200; Stratum G, 10,20012,800; Stratum H, 12,800-13,000; and Stratum I, $13,000-13,500 \mathrm{cal}$ BP. The 2 test pits dug in Cave A by Snethkamp, Guthrie, and Morris contained sediments that were heavily disturbed and can only be assigned a general age of terminal Pleistocene-Holocene.

Cave of the Chimneys (CA-SMI-603), a multicomponent archaeological-paleontological site, is located east of Daisy Cave (Fig. 1). This east-facing rockshelter is approximately $10 \mathrm{~m}$ (33 ft.) deep by $12 \mathrm{~m}$ (39 ft.) wide with intact, finely stratified sediments filling the interior of the cave to within a meter or less of the ceiling (Ainis et al. 2011, Ainis and Vellanoweth 2012). Between 1997 and 1999, a total of $1588 \mathrm{~L}$ of sediment were excavated by Vellanoweth, Erlandson, and Rick from a $1 \times$ 0.5-m unit situated along the north wall of the cave to a depth of almost $2 \mathrm{~m}$ before bedrock was reached (Ainis et al. 2011, 2014, Allen 2013). In addition, 4-L bulk samples (36 L total) were excavated from the east wall of Unit 1 once excavation of this unit was complete (Allen 2013). Stratigraphic layers were followed during excavation with arbitrary $10-\mathrm{cm}$ levels used within strata as needed (Allen 2013). Except for the bulk samples, sediments were screened on-site through a 1/8-inch mesh with residuals kept and transported back to the lab for further processing. In the laboratory, residuals were water-screened over a 1/16-inch screen and air-dried. This level of screening resulted in the collection of large quantities of microfauna, including bones from numerous small land birds. All avian remains recovered from the 16-inch screen residuals and bulk samples from Unit 1 were analyzed for the current study. Excavations revealed 7 stratigraphically discrete layers, which spanned approximately 7100 years of the Holocene (Ainis et al. 2011, 2014, Allen 2013). A total of $22{ }^{14} \mathrm{C}$ dates obtained from samples of marine shell and charcoal recovered from strata and levels of Unit 1 (Appendix 1) were used to establish a tight chronological stratigraphy for this site, as follows: Stratum I, 960-1070 cal BP; Stratum II, 2190-3800 cal BP; Stratum III, 3950-4190 cal BP; Stratum IV, 4210-4430 cal BP; Stratum V, 4240-5850 cal BP; Stratum VI, 6650-8460 cal BP; and Stratum VII, 7800-8070 cal BP (Vellanoweth et al. 2002, 2003, Allen 2013). Artifacts recovered from excavated strata of Unit 1 indicate that the cave was intermittently occupied for short periods of time by humans, with Barn Owls inhabiting the cave when humans were absent (Vellanoweth et al. 2003, Allen 2013).

\section{Methods}

Unidentified small avian bone recovered from fossil sites and cave/rockshelter deposits on San Miguel and Santa Rosa Islands were identified by P. Collins, D. Guthrie, and E. Whistler to the lowest taxonomic classification possible through direct comparison with modern skeletons in collections at the Santa Barbara Museum of Natural History (SBMNH) and the Natural History Museum of Los Angeles County (LACM). The suite of species initially used for identification of passerine bone included representatives from all families of Passeriformes recorded from the Channel Islands, with a selection of genera and species that occur today as resident breeders, seasonal migrants, or winter visitors to the northern Channel Islands (Collins and Jones 2015). Identifying passerine bones to genera or species was challenging due in part to their 
small size and difficult-to-discern characters. Osteological characters presented in Hamon (1964) were used first to assess family-level identification of passerines. Also, a variety of sources containing osteological descriptions and illustrations of fossil bird bone were consulted to help with identification (Miller 1925, 1929, 1932, Howard 1929, 1944, Hamon 1964, Gilbert et al. 1996, Campbell 2013). With careful examination, it was possible to find diagnostic features on small passerine bones that could be used for species-, genus-, or familylevel identification. Skeletal elements that could be identified included rostrum (premaxilla), mandible, quadrate, coracoid, scapula, humerus, ulna, carpometacarpus, femur, tibiotarsus, tarsometatarsus, and pygostyle.

Information recorded for each bone, besides species identification, included site provenience, skeletal element, body side, estimated age, and element configuration (complete, proximal, distal, medial, or fragment). For each taxon identified from a specific fossil locale, the number of identified specimens (NISP) was recorded based on the number of individual bones or bone fragments identified to that taxon. The minimum number of individuals (MNI) was determined by counting the most abundant paired or unique skeletal element for each taxon from a fossil site which lacked identifiable strata. For sites where samples were separated by stratum and level (e.g., CA-SMI-261, CA-SMI261A, and CA-SMI-603), MNI was calculated per stratum by counting the most abundant paired or unique skeletal element for each stratum, and then stratum MNI values were summed to arrive at total MNI for each taxon. This method of calculating MNI assumes no vertical mixing of faunal remains between strata, and as a result, MNI values are greater than if the most abundant paired element were used across strata to calculate MNI.

Bones from immature birds recovered from a fossil-subfossil context provide evidence documenting that a species was nesting prehistorically at a locale. However, determining age of bird bone is difficult, as most birds exhibit rapid skeletal maturity and do not show typical epiphyseal fusion of long bones, as seen with mammals (Serjeanston 2009). For most birds, their bones are fully ossified by fledging, leaving almost no characters useful for separating adults from juveniles/immatures
(Serjeanston 2009). Despite this difficulty of aging bird bone, von den Driesch et al. (2005) and Gilbert et al. (1996) identified a variety of characters (i.e., degree of bone ossification, incomplete development of epiphyses and articular surfaces, and bone porosity of proximal and distal ends of long bones) that can be used to separate bird bone into at least 4 age categories (very young, immature, subadult, and adult). Very young birds (hatchlings/young nestlings) have bones that are generally less than $50 \%$ ossified, while immature birds (older nestlings) show bones that are more than $50 \%$ ossified with incomplete development of epiphyseal ends of long bones (von den Driesch et al. 2005). Subadult birds (recent fledglings) have fully ossified bones that show slight porosity of the epiphyseal ends of the long bones, while bones of adult birds are fully ossified and show no evidence of porosity (von den Driesch et al. 2005). Porous and underdeveloped distal or proximal ends of long bones were used to identify immature and juvenile bird bone in the current study.

Taxonomy used in this paper includes all changes accepted by the American Ornithologists' Union to the 7th edition of the Check-list of North American Birds (AOU 1998) through the 58th supplement to this checklist (Chesser et al. 2017). For condors and caracaras, the nomenclature used in this paper is more complicated. There has been much debate regarding the validity of the Pleistocene species of condor (Gymnogyps amplus) being distinct from the modern California Condor (G. californianus). Condor remains recovered from fossil sites on the northern Channel Islands were found by Guthrie (1992b) to be within the range of the larger Rancho La Brea species Gymnogyps amplus. Guthrie (1992b) followed Emslie's (1988) assignment of all Pleistocene condor material to the recent species (Gymnogyps californianus), with amplus retained as a subspecies. However, recent work by Syverson and Prothero (2010) confirmed the validity of G. amplus as a species distinct from the modern California Condor (G. californianus), which we follow here. For caracara recovered from fossil sites on the islands, we use the currently accepted name for the Crested Caracara (Caracara cheriway) with the fossil species (Polyborus prelutosus) described from Rancho La Brea and Santa Rosa Island (Howard 1938, 1962) being retained as a subspecies, 
prelutosus. While a number of endemic subspecies of land birds breed today on the northern Channel Islands (Collins and Jones 2015), all fossil landbird remains reported in our study were identified to species only, rather than to the inferred endemic subspecies that breed on these islands today.

\section{RESULTS}

Table 1 provides an updated listing of the fossil/prehistoric avifauna of San Miguel and Santa Rosa Islands and is based on the identification to genus or species of 22,283 bones from 23 fossil sites on San Miguel Island (NISP = 22,047 ) and from a series of fossil sites on Santa Rosa Island (NISP = 236). Our study has increased the fossil avifauna for these 2 islands from 83 to 147 species, contributing 64 new species. San Miguel Island had the greatest number of new species added $(n=$ $62)$, while Santa Rosa had the fewest $(n=16)$. Most of the new species were from the orders Passeriformes (41 species), Charadriiformes (11 species), Piciformes (3 species), and Procellariiformes ( 3 species). Families with the greatest number of new species recorded included Passerellidae (8 species), Turdidae (6 species), Icteridae (5 species), and Scolopacidae (5 species). The greatest number of identified specimens (NISP) were from the family Alcidae $($ NISP $=15,848,71.1 \%$ NISP), followed by 13 passerine families (NISP $=2147,9.6 \%$ NISP), waterfowl (Anatidae, NISP $=2300$, $10.3 \%$ NISP), and cormorants (Phalacrocoracidae, NISP $=680,3.1 \%$ NISP). Aquatic birds (marine birds, waterfowl) comprised most of the identified remains ( $88.3 \%$ NISP), with passerine and nonpasserine land birds $(11.2 \%$ NISP), shorebirds $(0.5 \%$ NISP), and freshwater waders (herons, ibis, rails, and cranes; $0.04 \%$ NISP) making up the remainder.

Fossil sites that were the result of the accumulation of prey remains transported by Bald Eagles (SMI-V-7, 12, and 16) or Barn Owls (SMI-V-20, CA-SMI-261A, CA-SMI-603) exhibit differences in the taxonomic mix, diversity, and relative abundance of species when compared with sites that were the result of the accumulation of avian remains from being in proximity to seabird nesting colonies (SMI-V-6, 7, 10, 12, and 15-19; Guthrie 2005). Presence of eggshell fragments, immature bone, and an abundance of skeletal remains of nesting waterfowl (Chendytes lawi) and/or burrow-nesting seabirds (Ancient Murrelet, Cassin's Auklet, and Fratercula dowi) characterize fossil sites on San Miguel Island that were in close proximity to or were prehistoric seabird nesting colonies (Guthrie 2005). Prehistoric Bald Eagle nest sites exhibited a higher diversity and abundance of aquatic species (waterfowl, shearwaters, and alcids) than of smaller shorebirds and passerine and nonpasserine land birds (Collins et al. 2005, Guthrie 2005). Owl-generated fossil deposits showed a higher diversity and abundance of smaller seabirds (storm-petrels, alcids), shorebirds, and terrestrial birds (nonpasserine and passerine land birds) than of larger species like waterfowl and seabirds (Tables 1, 2). Terrestrial birds ranged from $42.6 \%$ to $74.3 \%$ NISP for owl-generated deposits but declined for other non-owl-generated fossil sites on Santa Rosa $(22.5 \%$ NISP) and San Miguel (1.0\% NISP). Decline in the abundance (13.9\% NISP) of small terrestrial birds in Rozaire's samples from Daisy Cave (CA-SMI-261) was due to the larger mesh size used to fieldscreen excavated samples, which resulted in the loss of most small bird bone. Raptors represented the majority of terrestrial bird remains recovered from fossil sites on Santa Rosa Island. Aquatic birds were most common in fossil sites (77.4\%-98.9\% NISP) and in Daisy Cave (87.4\% NISP), and were less common $(22.8 \%-57.8 \%$ NISP) in owl-generated deposits (Table 2). Percent NISP for passerines ranged from $38.9 \%$ to $72.6 \%$ for owlgenerated deposits but declined for fossil sites on Santa Rosa (5.9\% NISP) and San Miguel $(0.2 \%$ NISP). The greatest number of identified passerine bones were from these 5 passerine families: Passerellidae, Icteridae, Alaudidae, Turdidae, and Fringillidae.

\section{San Miguel Island Fossil Sites}

Although Guthrie (1992b, 1993, 2005) reported on 19 of the 20 sites he excavated on San Miguel Island, we identified another 107 small avian bones from these localities. This brings the total number of bones identified from these 19 fossil sites to 16,942, representing 68 species. Nearly all of the bird bone identified was from marine birds (NISP $=14,791,87.3 \%$ NISP, 28 species) and waterfowl $($ NISP $=1957,11.6 \%$ NISP, 7 species $)$. Alcids made up $85.8 \%$ NISP of the avian bone 


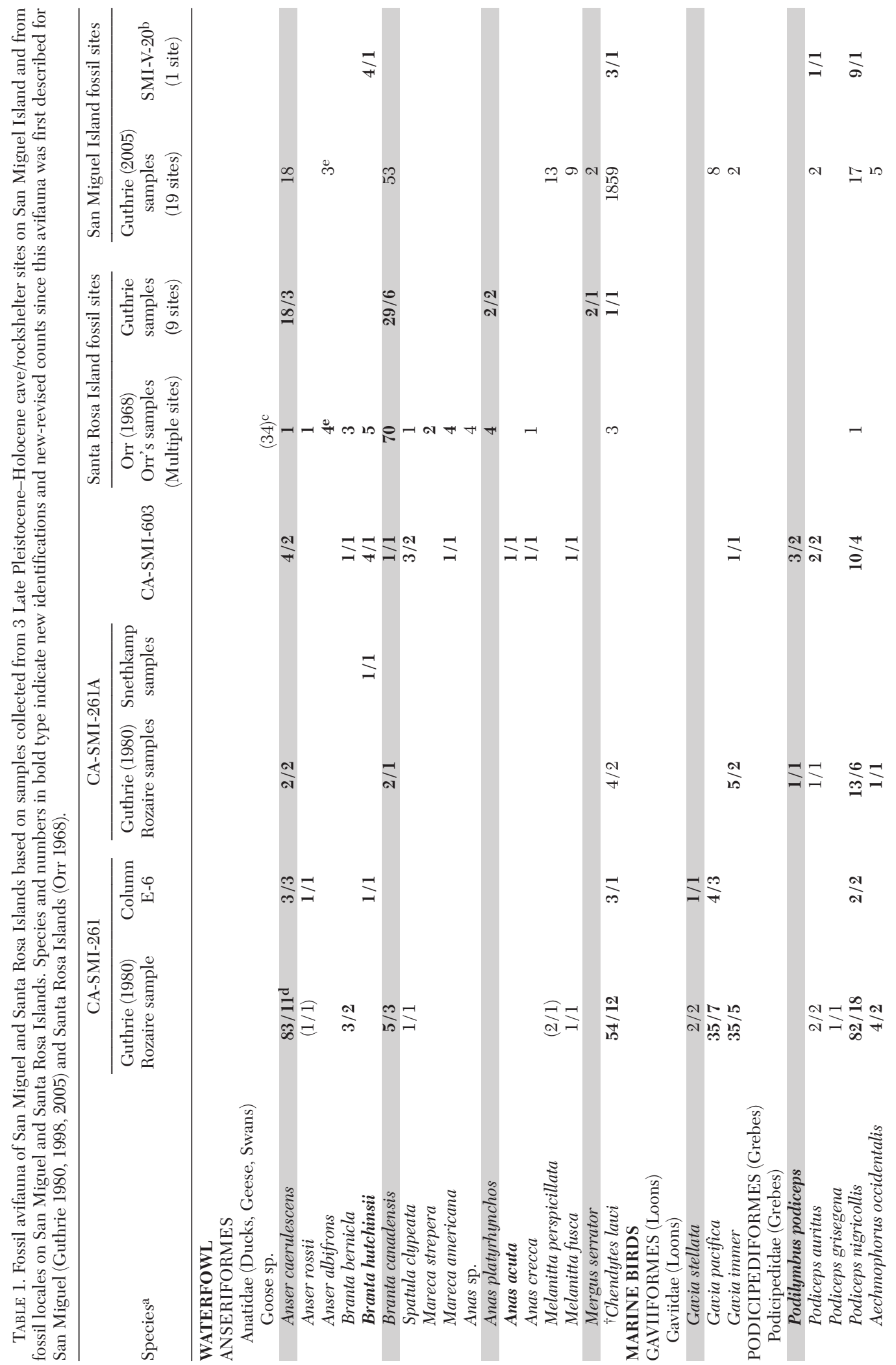


Collins et al. - Avian Remains on San Miguel and Santa Rosa

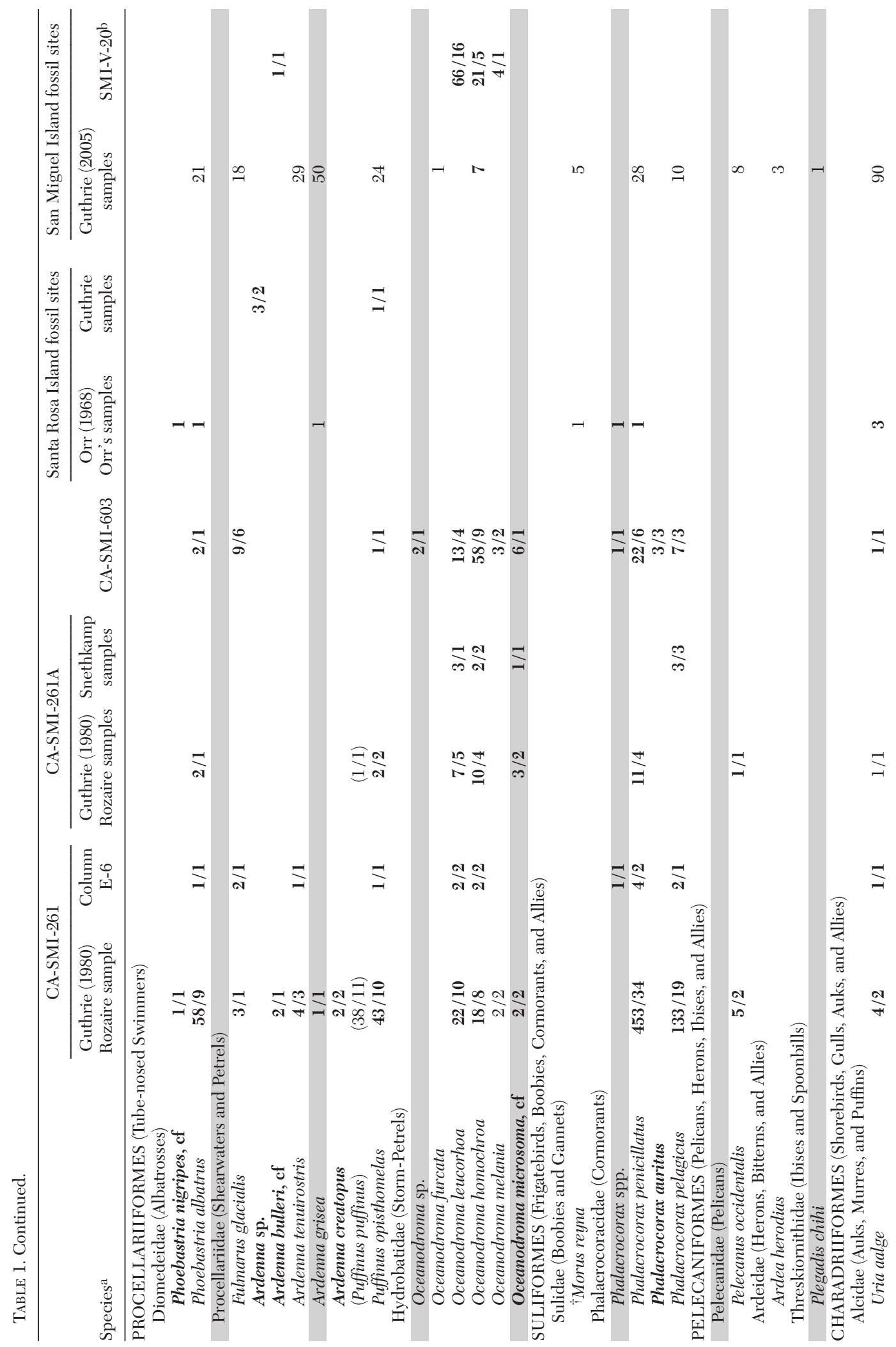




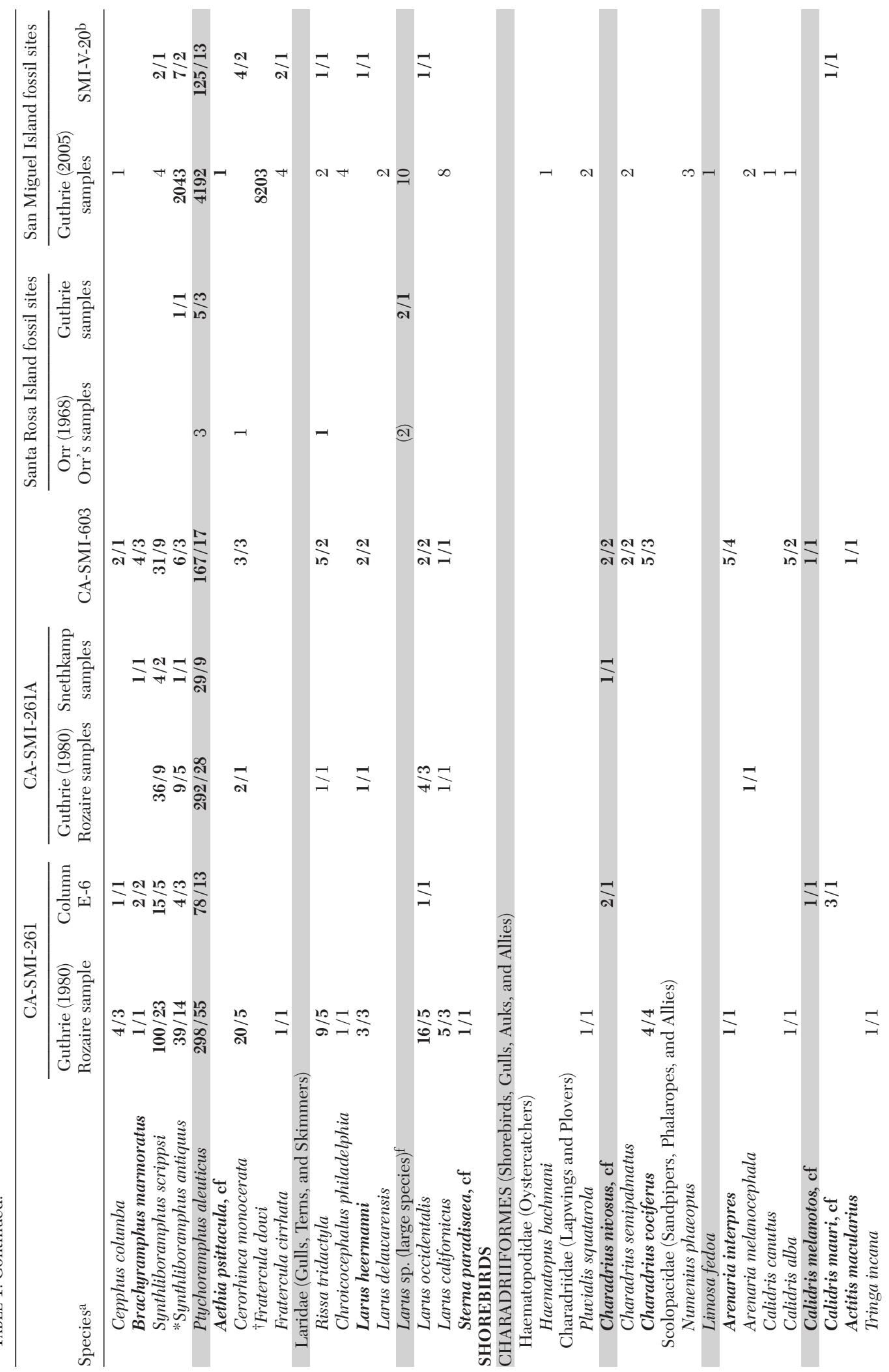


Collins et al. - Avian Remains on San Miguel and Santa Rosa

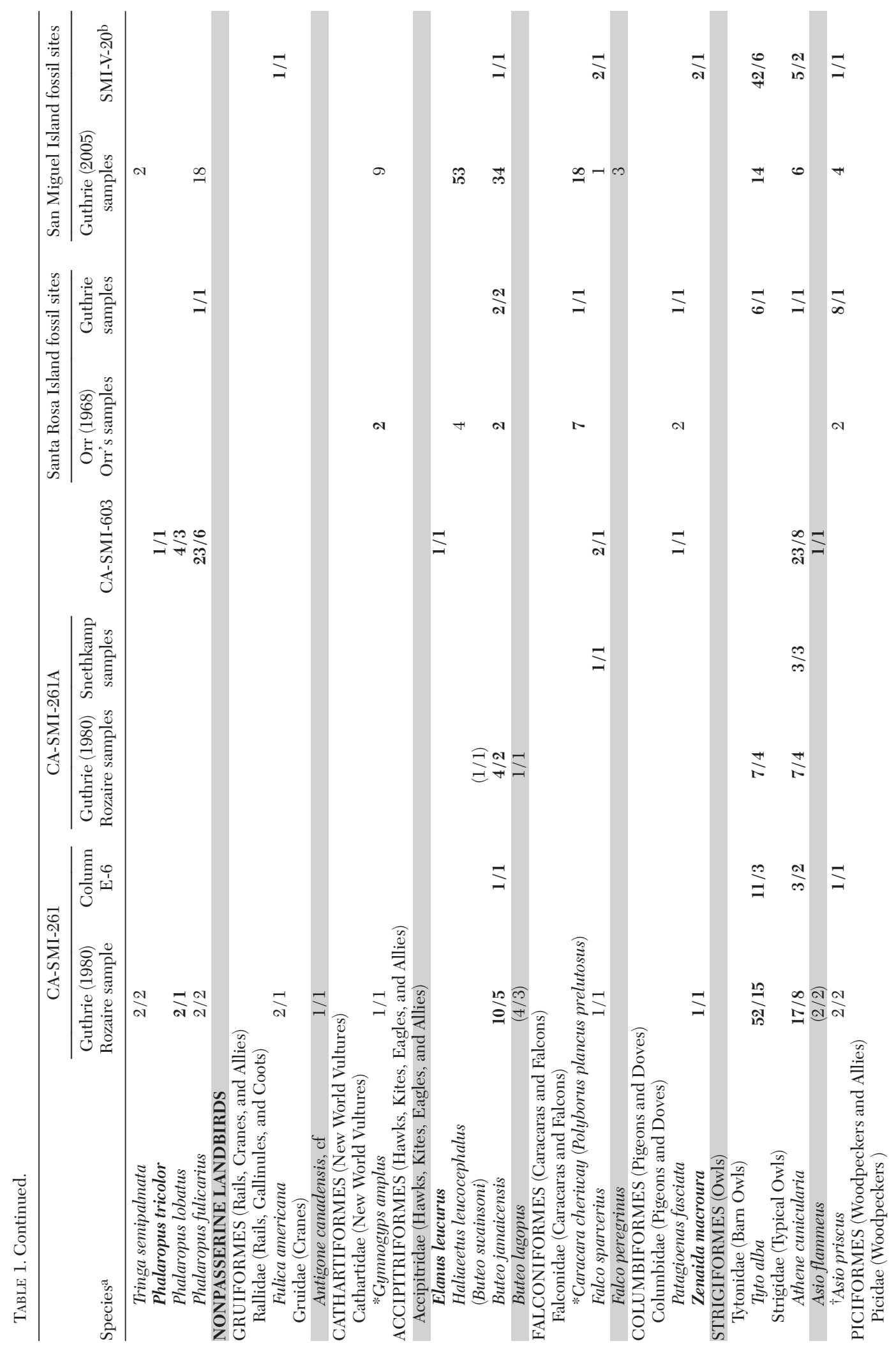




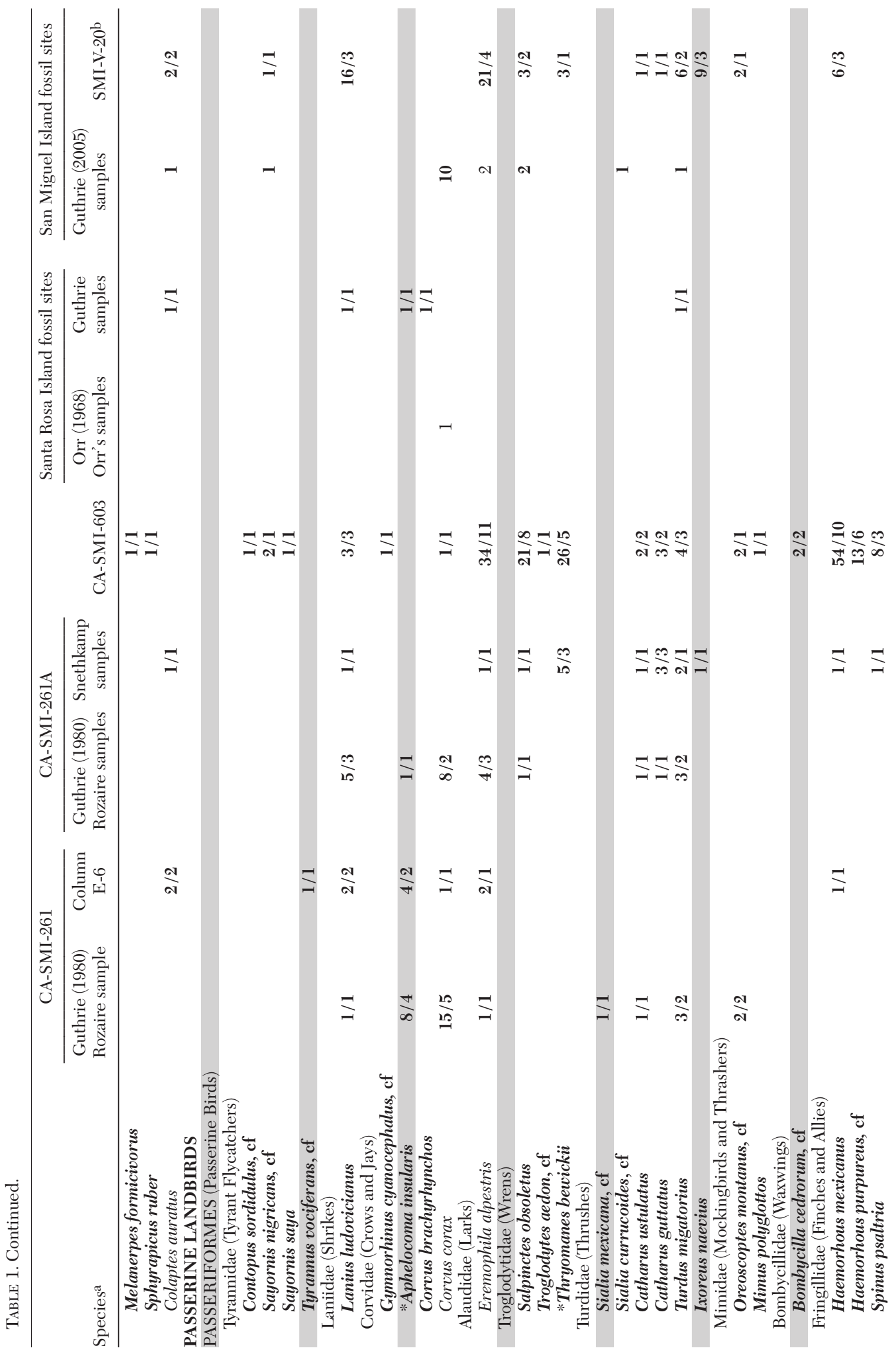




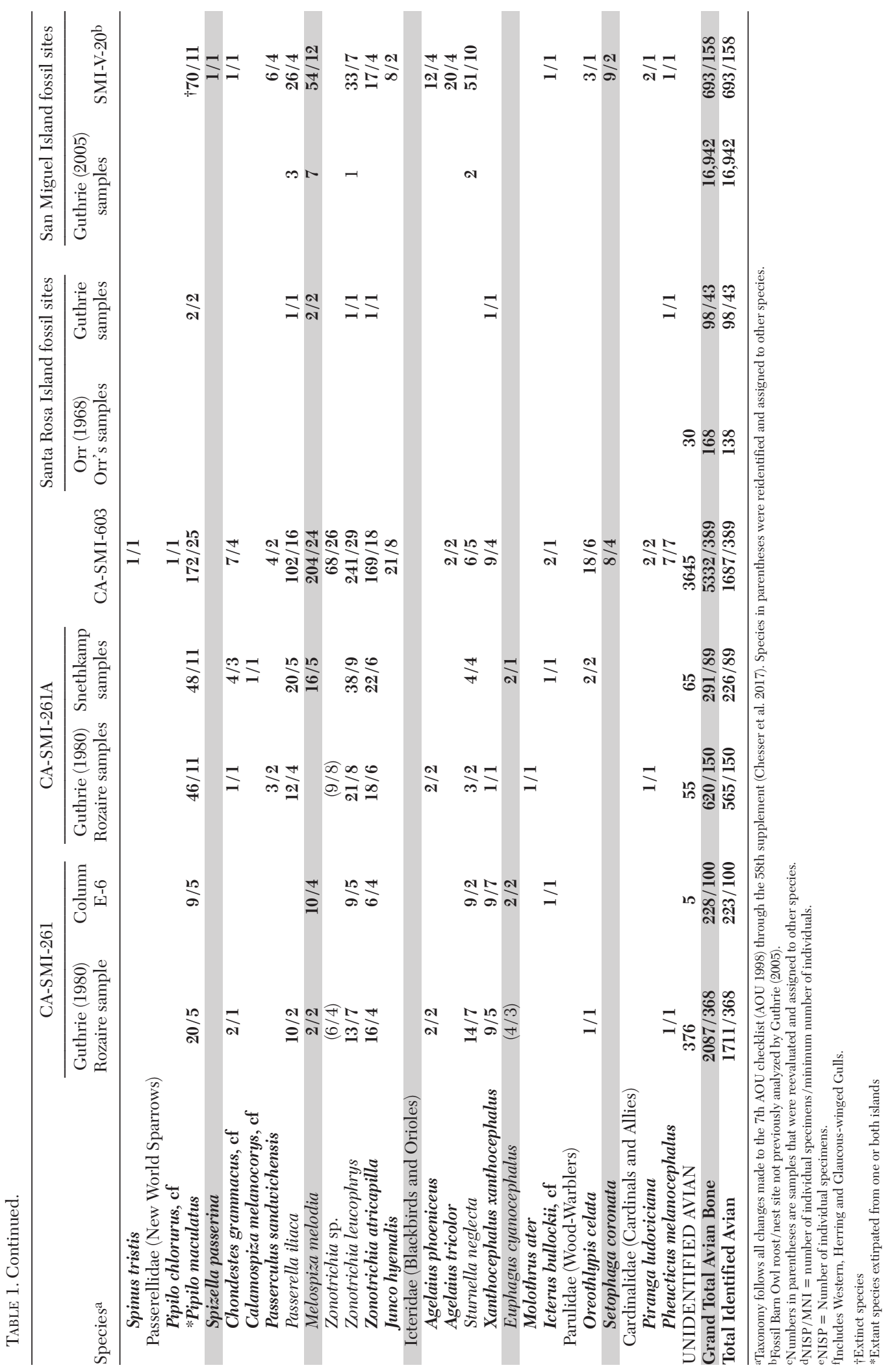


TABLE 2. Relative abundance (\%NISP) of avian ecological groups recovered from fossil sites and Barn Owl-generated fossil deposits on San Miguel and Santa Rosa Islands.

\begin{tabular}{|c|c|c|c|c|c|c|}
\hline \multirow[b]{2}{*}{ Species } & \multicolumn{2}{|c|}{ Fossil sites } & \multicolumn{4}{|c|}{ Barn Owl-generated fossil deposits } \\
\hline & SRI & SMI & SMI-V-20 & CA-SMI-603 & CA-SMI-261 & CA-SMI-261A \\
\hline Aquatic birds & $77.1^{\mathrm{a}}$ & 98.9 & 36.4 & 22.8 & 87.4 & 57.8 \\
\hline Waterfowl & 65.7 & 11.6 & 1.0 & 1.0 & 8.0 & 1.1 \\
\hline Marine birds & 11.4 & 87.3 & 35.4 & 21.8 & 79.4 & 56.6 \\
\hline Shorebirds & 0.4 & 0.2 & 0.1 & 2.9 & 1.0 & 0.3 \\
\hline Terrestrial birds & 22.5 & 1.0 & 63.5 & 74.3 & 13.9 & 42.0 \\
\hline Nonpasserines & 16.5 & 0.8 & 8.1 & 1.8 & 4.2 & 3.0 \\
\hline Passerines & 5.9 & 0.2 & 55.4 & 72.6 & 9.7 & 38.9 \\
\hline
\end{tabular}

a $\%$ ISP $=$ percent number of identified specimens

identified from Guthrie's 19 fossil sites. The remaining identified bones were from shorebirds (NISP $=33,0.2 \%$ NISP, 10 species), nonpasserine land birds (NISP $=143,0.8 \%$ NISP, 12 species), and passerine songbirds (NISP $=$ $30,0.2 \%$ NISP, 10 species). Of the 68 species identified, 6 were new to this fossil avifauna of San Miguel Island, with 4 passerine songbirds (Sayornis nigricans, Salpinctes obsoletus, Sialia currucoides, and Turdus migratorius), 1 alcid (Aethia psittacula), and 1 woodpecker (Colaptes auratus). The relatively small number of land bird bones represented in samples excavated by Guthrie from fossil sites on San Miguel was probably due to the type of sites excavated, not the mesh size used to screen excavated sediments in the field.

In addition to Guthrie's 19 published localities, 693 previously unidentified bones from 53 species of birds $(\mathrm{MNI}=157)$ were identified from SMI-V-20, a 7300-year-old fossil Barn Owl roost site located along the northwest shore of San Miguel Island. The most diverse group of birds represented in this sample was passerine land birds (order Passeriformes), with 384 bones (55.4\% NISP) of 28 species from 11 families. Most of the passerines identified were from 3 families (Passerellidae, Icteridae, and Turdidae). Owls (Strigiformes) composed the next largest sample of identified land bird bone with 48 bones $(6.9 \%$ NISP) from 9 individuals $(5.8 \%$ MNI) of 3 species. Marine birds made up $29.5 \%$ MNI of the sample with a total of 14 species represented. Storm-petrels (Hydrobatidae, NISP $=91$ ) and alcids (Alcidae, NISP $=140$ ) were the most abundant marine birds identified from this site. The remaining sample comprised small samples of bone from waterfowl $(\mathrm{NISP}=7)$, grebes $(\mathrm{NISP}=$ $10)$, gulls $(\mathrm{NISP}=3)$, shorebirds $(\mathrm{NISP}=1)$, falcons (NISP $=2)$, doves $($ NISP $=2)$, and woodpeckers (NISP $=2$ ).

\section{San Miguel Island Cave/Rockshelter Sites}

Previously unidentified avian remains from 3 cave/rockshelter sites used intermittently by Barn Owls and humans (CA-SMI-261, CASMI-261A, and CA-SMI-603) are included in the current study. Guthrie (1980) reported on the fossil avifauna of Daisy Cave (CA-SMI261 and CA-SMI-261A), but most of the small bird bones recovered by Rozaire remained unidentified, including numerous passerine bones $(n=223$ bones). These unidentified small avian remains, along with several recent samples from Daisy Cave (Column E-6) and Cave of the Chimneys (CA-SMI-603) not previously examined by Guthrie, are included in the current study.

Previous work on the avifauna from the Daisy Cave rockshelter (CA-SMI-261) identified a total of 1406 bones from 53 species (Guthrie 1980). We identified an additional 528 bird bones, bringing the total number of bones identified to 1934 . We also increased the number of species recorded for this site from 53 to 88 . Most of the birds from Daisy Cave were marine birds $(\mathrm{MNI}=308,62.1 \%$ $\mathrm{MNI})$, with cormorants $(\mathrm{MNI}=57,11.5 \%$ MNI), alcids (MNI $=129,26.0 \% \mathrm{MNI}$ ), and tube-nosed birds $(\mathrm{MNI}=58,11.7 \% \mathrm{MNI})$ composing the majority of identified marine bird bone. Waterfowl accounted for 7.5\% MNI $(\mathrm{MNI}=37)$ of the identified sample, while land birds made up 26.8\% MNI (MNI = 133). The largest number of new species added to the Daisy Cave avifauna by our study were from the order Passeriformes (18 new species) and Charadriiformes (5 new species). A total of 187 bones (9.7\% NISP) of 92 individuals (18.5\% MNI) from 29 species of passerines 
were identified. The largest number of identified passerine bones and species were from the families Passerellidae (NISP $=97, \mathrm{MNI}=39$, 6 species), Icteridae (NISP $=46, \mathrm{MNI}=26$, 5 species), and Corvidae (NISP $=28$, MNI $=$ 12, 2 species). Two extinct species (Chendytes lawi, Asio priscus) and 4 extant species that no longer breed today on San Miguel Island (Synthliboramphus antiquus, Gymnogyps amplus, Aphelocoma insularis, and Pipilo maculatus) were recorded in the Daisy Cave avifauna.

Within the assemblage from Cave $\mathrm{A}$ at Daisy Cave, Guthrie (1980) identified 451 bones from 26 species. We identified an additional 340 bird bones, bringing the total number of bones identified from Cave A to 791 and the number of species to 63. Over threefourths of the birds identified from this site were passerine songbirds $(\mathrm{MNI}=121,56.0 \%$ MNI, 28 species), auklets (MNI $=57,23.4 \%$ MNI, 6 species), and storm-petrels ( $\mathrm{MNI}=$ 15, 6.9\% MNI, 3 species; Table 1). Over half of the identified individuals $(\mathrm{MNI}=139,56.3 \%$ $\mathrm{MNI}$ ) were terrestrial birds (passerines, hawks, falcons, owls, and woodpeckers), with aquatic birds comprising most of the remaining individuals $(\mathrm{MNI}=106,42.9 \% \mathrm{MNI})$. Passerines accounted for a total of 123 identified individuals of 28 species from 10 families, with the majority coming from 3 families: Emberizidae (30.3\% MNI), Icteridae (5.0\% MNI), and Turdidae $(4.2 \% \mathrm{MNI})$. Aquatic birds accounted for 106 individuals of 27 species from 10 families, most coming from Alcidae (23.1\% MNI), Hydrobatidae (6.0\% MNI), and Podicipedidae (3.6\% MNI). The 5 most common species identified from Cave A samples were Cassin's Auklet $(\mathrm{MNI}=37)$, Spotted Towhee $(\mathrm{MNI}=$ 22), White-crowned Sparrow (Zonotrichia leucophrys; $\mathrm{MNI}=17$ ), Golden-crowned Sparrow (Z. atricapilla; MNI $=12)$, and Scripps's Murrelet (Synthliboramphus scrippsi; MNI = 11). The greatest number of new species added to the Cave A avifauna were passerine songbirds (24 new species). Passerines accounted for a total of 308 identified bones (38.9\% NISP) of 123 individuals (49.8\% MNI) from 28 species. The largest number of passerine bones and species were from Passerellidae $(\mathrm{NISP}=250, \mathrm{MNI}=78,8$ species$)$, Icteridae $(\mathrm{NISP}=14, \mathrm{MNI}=12,6$ species $)$, and Turdidae $(\mathrm{NISP}=12, \mathrm{MNI}=10,4$ species $)$. One extinct species (Chendytes lawi) and 4 extant species that no longer nest on San Miguel
Island (Synthliboramphus antiquus, Aphelocoma insularis, Thryomanes bewickii, and Pipilo maculatus) were recorded in the fossil avifauna from CA-SMI-261A.

The raptor-generated (falcon and owl) deposit at Cave of the Chimneys (CA-SMI603) represents the richest Holocene deposit of passerine bone recorded to date for the Channel Islands and for California. Of the 5332 bird bones recovered, 1687 (31.5\% NISP) were identified to genus or species. From these identified remains, 89 species from 11 orders and 29 families were recorded. Twenty-six of the 89 species recorded represent new species records for the fossil avifauna of San Miguel Island. These include 4 species of aquatic birds (waterfowl and cormorants), 3 shorebirds, 5 nonpasserine land birds (hawks, pigeons, owls, and woodpeckers), and 14 passerines. Aquatic birds made up about a quarter $(26.2 \%$ MNI) of the identified remains, while terrestrial birds accounted for most $(67.4 \% \mathrm{MNI})$ of the remaining identified sample. A total of 49 (2.9\% NISP) shorebird (plovers, sandpipers, and phalaropes) bones from 25 individuals (6.4\% MNI) of 10 species were identified. Passerines accounted for 1224 identified bones (72.6\% NISP) of 248 individuals (63.8\% MNI) from 38 species. The greatest number of identified passerine bones were from 4 families: Passerellidae $(\mathrm{NISP}=989, \mathrm{MNI}=153,10$ species), Fringillidae (NISP $=76, \mathrm{MNI}=20$, 4 species), Troglodytidae (NISP $=48, \mathrm{MNI}=$ 14, 3 species), and Alaudidae (NISP $=34, \mathrm{MNI}$ $=11,1$ species; Table 1 ). The most common aquatic birds were from 3 families: Alcidae (9.5\% MNI), Hydrobatidae (4.4\% MNI), and Phalacrocoracidae (3.3\% MNI). The most abundant species identified included 5 passerines (White-crowned Sparrow, Song Sparrow [Melospiza melodia], Spotted Towhee, Goldencrowned Sparrow, and Fox Sparrow [Passerella iliaca]), Ashy Storm-Petrel (Oceanodroma homochroa), and Cassin's Auklet. No extinct species were identified in samples excavated from Cave of the Chimneys; however, at least 3 extant species (Burrowing Owl [Athene cunicularia], Spotted Towhee, and Bewick's Wren) were present on San Miguel Island during the Holocene but likely disappeared from the island's resident breeding avifauna by the time the first ornithologists visited the island in the late 1800s. Burrowing Owl (NISP = 23) and Spotted Towhee remains $(\mathrm{NISP}=172)$ were 
TABLE 3. Juvenile/immature bird bone recovered from Late Pleistocene-Holocene sites on San Miguel Island, California.

\begin{tabular}{|c|c|c|c|c|c|c|c|c|}
\hline \multirow[b]{2}{*}{ Species } & \multicolumn{4}{|c|}{ San Miguel Island fossil sites } & \multicolumn{3}{|c|}{ San Miguel Island cave sites } & \multirow[b]{2}{*}{ Total NISPa } \\
\hline & V-6 & $\mathrm{V}-7$ & V-18 & $\mathrm{V}-20$ & 261 & $261 \mathrm{~A}$ & 603 & \\
\hline Puffinus opisthomelas, cf & & & & & $1^{\mathrm{a}}$ & & & 1 \\
\hline Oceanodroma homochroa & & & & & & & 4 & 4 \\
\hline Phalacrocorax pelagicus & & & & & 3 & & & 3 \\
\hline Charadrius nivosus, of & & & & & & & 1 & 1 \\
\hline Cepphus columba & & & & & 1 & & & 1 \\
\hline Synthliboramphus scrippsi & & & & & & & 2 & 2 \\
\hline Ptychoramphus aleuticus & & & & & 2 & & 3 & 5 \\
\hline Cerorhinca monocerata & & & & 1 & & & & 1 \\
\hline Fratercula cirrhata, of & & & & & 1 & & & 1 \\
\hline Larus occidentalis & & & & 1 & & & 1 & 2 \\
\hline Tyto alba & & & 1 & 1 & 9 & 2 & & 13 \\
\hline Athene cunicularia, of & & & & & & 1 & 1 & 2 \\
\hline Sayornis nigricans, of & & 1 & & 1 & & & 1 & 3 \\
\hline Lanius ludovicianus & & & & 1 & & & 1 & 2 \\
\hline Aphelocoma insularis & & & & & 2 & & & 2 \\
\hline Corvus corax & & & & & 4 & 8 & 1 & 13 \\
\hline Eremophila alpestris & & & & 1 & & 1 & 3 & 5 \\
\hline Salpinctes obsoletus, of & 1 & & & & & 1 & 2 & 4 \\
\hline Pipilo maculatus & & & & 1 & & & 3 & 4 \\
\hline Melospiza melodia & & & & 2 & & & 13 & 15 \\
\hline Sturnella neglecta & & & & 2 & 4 & 2 & 1 & 9 \\
\hline Haemorhous mexicanus & & & & & & & 5 & 5 \\
\hline Number of SPECIES & 1 & 1 & 1 & 9 & 9 & 6 & 15 & \\
\hline
\end{tabular}

found in all 7 strata excavated, confirming that both species were present on the island from as early as $8030 \mathrm{cal} \mathrm{BP}$ until as late as $950 \mathrm{cal}$ BP. Bewick's Wren remains (NISP $=26$ ) were recovered from 4 strata, confirming its presence on the island from as early as 8030 cal BP to as late as $2190 \mathrm{cal} \mathrm{BP}$.

\section{Fossil Avifauna of Santa Rosa Island}

A total of 236 bird bones recovered from Late Pleistocene-Holocene sites on Santa Rosa Island by Orr (NISP = 138) and Guthrie $($ NISP $=98)$ yielded an avifauna composed of 48 species, with $77.4 \%$ of the sample made up of aquatic species such as waterfowl (13 species, $65.7 \%$ NISP) and a variety of marine birds (14 species, 11.4\% NISP). Terrestrial birds were less common, with 53 bones $(22.5 \%$ NISP) identified from 20 species. Half of the terrestrial birds were passerines (10 species, $5.9 \%$ NISP), with raptors (hawks, caracara, and owls) making up most of the remaining land birds ( 7 species, 7.6\% NISP). The largest number of species added to the fossil avifauna of Santa Rosa Island were Passeriformes (9 new species) and Anseriformes (5 new species). Nine new passerine species were recorded from Guthrie's recent samples, including Loggerhead Shrike (Lanius ludovicianus), American
Crow (Corvus brachyrhynchos), Island ScrubJay (Aphelocoma insularis), American Robin (Turdus migratorius), Spotted Towhee, Fox Sparrow, Song Sparrow, White-crowned Sparrow, and Golden-crowned Sparrow. Four extinct species (Chendytes lawi, Morus reyna, Gymnogyps amplus, and Asio priscus), and 2 extant species (Caracara cheriway prelutosus and Aphelocoma insularis) that no longer occur on Santa Rosa Island were also recorded. A single Island Scrub-Jay femur was identified from SRI-V-3, a Late Pleistocene site, which confirms the prehistoric occurrence of this island endemic on Santa Rosa Island.

\section{Juvenile/Immature Birds}

Ninety-eight bones of juvenile/immature birds from 22 species were identified from the small avian remains we examined (Table 3). The majority of immature bones (95 bones, 96.9\% NISP) were from owl-generated deposits, including 1 prehistoric owl roost and 3 cave/rockshelter sites on San Miguel Island (Table 3). Cave of the Chimneys had the greatest number of juvenile bones (NISP $=42)$ and the most species $(n=15)$. Most of the identified bones were from Passeriformes (62 bones, 10 species) and Charadriiformes (13 bones, 7 species). The majority of juvenile bone was from 3 
TABLE 4. Prehistoric occurrences of Island Scrub-Jay (Aphelocoma insularis) bone in sites of Pleistocene-Holocene age on San Miguel and Santa Rosa Islands, Santa Barbara County, California.

\begin{tabular}{|c|c|c|c|}
\hline Site/provenience & $\begin{array}{l}\text { Calendar age } \\
\text { range }(\text { cal. BP) }\end{array}$ & Element/side/portion & Institution ${ }^{b}$ \\
\hline \multicolumn{4}{|c|}{ CA-SMI-261 Daisy Cave (Rozaire's samples) } \\
\hline Unit D5, $0^{\prime \prime}$ to $6^{\prime \prime}$ & Late Holocene & Femur/right/proximal & LACM \\
\hline Unit D5, $36^{\prime \prime}$ to $42^{\prime \prime}$ & Trans-Holocene & Tarsometarsus/left/distal & LACM \\
\hline Unit D5, $36^{\prime \prime}$ to $42^{\prime \prime}$ & Trans-Holocene & Tarsometarsus/right/shaft & LACM \\
\hline Unit E5, $24^{\prime \prime}$ to $36^{\prime \prime}$ & Trans-Holocene & Ulna/left/distal & LACM \\
\hline Unit F5, 36" to $42^{\prime \prime}$ & Trans-Holocene & Ulna/left/complete & LACM \\
\hline Unit F5, $54^{\prime \prime}$ to $60^{\prime \prime}$ & Trans-Holocene & Ulna/left/complete & LACM \\
\hline Unit $\mathrm{H} 5,36^{\prime \prime}$ to $42^{\prime \prime}$ & Trans-Holocene & Femur/left/proximal & LACM \\
\hline Unit $\mathrm{H} 5,48^{\prime \prime}$ to $54^{\prime \prime}$ & Trans-Holocene & Tibiotarsus/right/distal & LACM \\
\hline \multicolumn{4}{|c|}{ CA-SMI-261 Daisy Cave (Column E-6) } \\
\hline Test Unit C/5-6, Stratum E1-A & ～8900-8480 & $\begin{array}{l}\text { Tarsometarsus/right/ } \\
\text { distal \& shaft (immature) }\end{array}$ & $\mathrm{UO}$ \\
\hline Test Unit C/5-6, Stratum E1-B & ８900-8480 & Tibiotarsus/right/distal & $\mathrm{UO}$ \\
\hline Test Unit D/5-6, Stratum E1-B & $\sim 8900-8480$ & $\begin{array}{l}\text { Humerus/right/proximal } \\
\text { (immature) }\end{array}$ & $\mathrm{UO}$ \\
\hline Test Unit D6, Stratum H & $\sim 12,400-11,800$ & Tibiotarsus/right/distal & $\mathrm{UO}$ \\
\hline \multicolumn{4}{|c|}{ CA-SMI-261A Daisy Cave (Rozaire’s samples) } \\
\hline Test Pit $1,6^{\prime \prime}$ to $12^{\prime \prime}$ & Mixed: Holocene & Tarsometarsus/left/distal & LACM \\
\hline \multicolumn{4}{|l|}{ SRI-V-3 } \\
\hline Lower Tecolote Member & Late Pleistocene: & Femur/left/complete & SBMNH-VP 423 \\
\hline
\end{tabular}

passerines (Song Sparrow, Common Raven, and Western Meadowlark [Sturnella neglecta]), Barn Owl, and Cassin's Auklet.

All but 4 (Black-vented Shearwater [Puffinus opisthomelas], Burrowing Owl, Island ScrubJay, and Spotted Towhee) of the 22 species identified are known to nest today or in the recent past on San Miguel Island (Collins and Jones 2015). A right femur of a juvenile seabird, tentatively assigned to Black-vented Shearwater, a more southern breeder, was recovered from Daisy Cave (Unit H5, level $54^{\prime \prime}$ to $60^{\prime \prime}$ ). Identification of juvenile Burrowing Owl, Black Phoebe, and Loggerhead Shrike bones confirms that all 3 species nested on San Miguel during the Holocene. Two juvenile Island Scrub-Jay bones (tarsometarsus, distal half; humerus, proximal end) were recovered from 2 Early Holocene (8900-8480 cal BP) levels of Column E-6 from Daisy Cave (Table 4). Four juvenile Spotted Towhee bones were identified, one from SMI-V-20, a Holocene ( 7300 years old) fossil Barn Owl roost, and the other 3 from 3 separate strata (I, III, and VII) at Cave of the Chimneys, spanning the Holocene from as early as 7790-7950 cal BP to as late as 960-1070 cal BP (Appendix 1). While identification of juvenile Burrowing Owl, Island Scrub-Jay, and Spotted Towhee bone confirms that these species probably nested on San Miguel during the Holocene, well-dated samples are lacking from the historic period that might help to determine when breeding populations of these 3 species disappeared from the island. Loss of dense scrub habitat on San Miguel Island following the arrival of herbivores to the island in the mid- to late 1800s likely resulted in the disappearance of scrub-inhabiting species like Bewick's Wren and Spotted Towhee, which nest today on Santa Rosa and Santa Cruz Islands.

\section{Extinct and Extirpated Avifauna}

The fossil avifauna of San Miguel and Santa Rosa Islands includes 5 extinct species (Chendytes lawi, Morus reyna, Fratercula dowi, Gymnogyps amplus, and Asio priscus) along with extant species that no longer occur on the northern Channel Islands (Caracara cheriway) or that nested prehistorically on San Miguel (Synthliboramphus antiquus, Athene cunicularia, Aphelocoma insularis, Thryomanes bewickii, and Pipilo maculatus) (Orr 1968, Guthrie 1980, 2005; current study). Terrestrial birds that have probably disappeared as resident breeders from San Miguel Island during or after the Holocene include Burrowing Owl, Island Scrub-Jay, Bewick's Wren, and Spotted 
Towhee. Of particular note was the occurrence of Island Scrub-Jay on both San Miguel and Santa Rosa during the Late PleistoceneHolocene. Fifteen Island Scrub-Jay bones were recovered from CA-SMI-261 and CA-SMI261A on San Miguel Island and from one fossil site (SRI-V-3) on Santa Rosa Island (Table 4). Nine Island Scrub-Jay bones from Rozaire's excavations at Daisy Cave and Cave A were from test units and levels that could span the Holocene (Table 4). Four bones from the more precisely dated Column E-6 from Daisy Cave were of Late Pleistocene through Early Holocene age, while the single Island ScrubJay bone from Santa Rosa Island was from a geologic formation of Late Pleistocene age. One Island Scrub-Jay bone from CA-SMI-261 was identified from a level that dates to the Late Holocene (Table 4), suggesting that this species could have disappeared from this island by the end of the Holocene. However, a statement made to Clark P. Streator in 1892 by $\mathrm{Mr}$. John Moore, the ranch foreman of Santa Rosa Island, that "... there are jays on the island" suggests that a small population of Island Scrub-Jays may have persisted on this island into the historic period (Collins 2009). If jays were present into the historic period on Santa Rosa Island, they were probably driven to extinction sometime in the late 1800 s as a result of the widespread loss of native vegetation from overgrazing by 80,000 to 100,000 sheep (Ovis aries) (Collins 2009, Morrison et al. 2011).

\section{Discussion}

The paleoavifauna of San Miguel and Santa Rosa Islands is among the richest Late Pleistocene-Holocene coastal avifaunal assemblages yet recorded for California. This fauna now includes 147 species, of which 62 are new additions to the Channel Islands fossil avifauna and 40 are being recorded for the first time to the fossil avifauna of California (Miller and DeMay 1942, Brodkorb 1978, Jefferson 1991, Guthrie 2009). San Miguel had the greatest number of species recorded, 146, while only 45 species were identified from the much smaller Santa Rosa Island sample. Although $88.5 \%$ of the identified bird bones $($ NISP $=19,713)$ were from aquatic species, they only constituted $39.7 \%$ of all avian species identified. Terrestrial birds, in contrast, made up $11.3 \%$ NISP of the identified bird bones (NISP $=2521$ ) but $47.3 \%$ of the species identified, with 48 of the 69 species $(32.9 \%)$ of terrestrial birds from the order Passeriformes. Shorebirds constituted $13 \%$ of the identified species but only $0.5 \%$ NISP of the identified bones (NISP $=106$ ). Use of finer mesh screens during recent excavations of cave deposits on San Miguel Island have resulted in the collection of more small bird bone than all previous excavations conducted at fossil sites on the island. For this reason, we recommend that all future excavations of fossil and subfossil deposits on the Channel Islands use $1 / 16$-inch mesh to screen excavated samples in the field, then transport the residuals to the lab for further processing through even finer mesh screens. Additional sampling of cave deposits on the Channel Islands should yield more microfossils that can be used to examine Quaternary environmental change on the Channel Islands.

\section{Aquatic Paleoavifauna}

Our identification of small bird bones from fossil sites on these 2 islands has mostly added to the number of identified bones for aquatic species already known to be part of this paleoavifauna. However, our study contributed 11 additional species of aquatic birds, including 1 goose (Branta hutchensi), 1 grebe (Podilymbus podiceps), 1 albatross (Phoebastria nigripes), 2 shearwaters (Ardenna bulleri and A. creatopus), 1 storm-petrel (Oceanodroma microsoma), 1 cormorant (Phalacrocorax auritus), 2 alcids (Brachyramphus marmoratus and Aethia psittacula), 1 gull (Larus heermanni), and 1 tern (Sterna paradisaea). Of these new additions, the Double-crested Cormorant is the only species that may have nested prehistorically on the northern Channel Islands where it is known to currently nest (Carter et al. 1992, 2008, Collins and Jones 2015). Seventeen species of aquatic birds recorded in the paleoavifauna of the northern Channel Islands are as yet unrecorded in the present-day avifauna of San Miguel and/or Santa Rosa Islands. A few of the more unusual aquatic species that have yet to be recorded at San Miguel or Santa Rosa Islands today include Red-necked Grebe (Podiceps grisegena), Least Storm-Petrel (Oceanodroma microsoma), Marbled Murrelet (Brachyramphus marmoratus), Parakeet Auklet, and Arctic Tern (Sterna paradisaea). Three of these species have more northern breeding 
ranges, while the Least Storm-Petrel has a more southern breeding range. All these species have been observed recently at one or more of the Channel Islands (Collins and Jones 2015).

The aquatic paleoavifauna of San Miguel and Santa Rosa Islands consists mostly of species known to occur today as seasonal migrants or winter visitors to the northern Channel Islands (Collins and Jones 2015). The exceptions include the prehistoric breeding occurrence of 2 extinct species (Chendytes lawi and Fratercula dowi) and 2 extant species (Synthliboramphus antiquus and Ptychoramphus aleuticus) (Guthrie 1992b, 2005). The abundance of bone of all 4 species along with the recovery of eggshells and immature bone confirm that these 4 species nested on San Miguel during the Late Pleistocene (Guthrie 1992b, 2005, Guthrie et al. 2002). For the 2 extant species, Cassin's Auklets nest today on San Miguel Island (Carter et al. 1992, 2008), while Ancient Murrelets no longer nest on this island but are a rare winter visitor to waters surrounding the Channel Islands (Collins and Jones 2015). We confirmed that 8 of the 14 species of marine birds known to nest today at San Miguel were nesting prehistorically on this island. An intact juvenile right femur referable to Black-vented Shearwater, a species that breeds today on islands off the Pacific Coast of central Baja California (Keitt et al. 2000), is unusual because this species has never been confirmed to nest historically on islands north of its current breeding range. This species was suspected of nesting historically on San Martin Island (AOU 1957). However, according to Everett (1988), the lack of adequate documentation to confirm breeding suggests that this purported breeding record is probably erroneous. Five species of storm-petrels were identified in the fossil record for San Miguel Island, 2 with more northern ranges (Fork-tailed and Leach's Storm-Petrels), 2 with more southern ranges (Least and Black Storm-Petrels), and one within its known breeding range (Ashy StormPetrel). Three species of storm-petrels nest today at San Miguel Island (Carter et al. 1992, 2008), but only Ashy Storm-Petrels were confirmed by the current study to nest prehistorically on the island. However, similarity in the number of identified bones of Ashy and Leach's Storm-Petrels from fossil sites on San Miguel Island suggests that both species probably nested prehistorically on this island. Aside from aquatic species that bred during the Quaternary on San Miguel Island, most of the other aquatic species identified in this fossil avifauna were represented by fewer bones. This probably results from the fact that many of these waterfowl and marine birds were food for raptors like Bald Eagles, Redtailed Hawks, and Peregrine Falcons (Falco peregrinus), who transported bones of these aquatic species to their nest and roost sites (Guthrie 1992b, 2005). All these raptors would have preyed upon live marine birds and waterfowl in nearshore aquatic habitats and would, in the case of Bald Eagles, have also scavenged on beach-cast seabird carcasses.

The source of the samples we used to confirm marine bird nesting differed from samples used to confirm breeding in prior work on the fossil avifauna of San Miguel Island. Guthrie (1992b, 2005) and Guthrie et al. (2002) recorded juvenile marine birds from immature bone and eggshells recovered from prehistoric marine bird breeding colonies and not from cave deposits of birds preyed upon by owls or falcons. Most juvenile marine bird bone identified during the current study was recovered from owl- or falcon-generated cave deposits, confirming that Barn Owls and Peregrine Falcons preyed on marine birds that nested on the island prehistorically. The assemblage of marine birds we documented as nesting prehistorically on San Miguel comprised mostly burrow- and crevice-nesting seabirds, like Ashy Storm-Petrel, Scripps's Murrelet, and Cassin's Auklet, but not marine birds that nested in sea caves and deeper crevices, like Pigeon Guillemot (Cepphus columba) and Tufted Puffin (Fratercula cirrhata), or in larger, more open colonies, like the 3 cormorant species, Rhinoceros Auklet (Cerorhinca monocerata), and Western Gull (Larus occidentalis).

\section{Shorebird Paleoavifauna}

Of the 19 species of shorebirds recorded in the paleoavifauna of the northern Channel Islands, only one species, Red Phalarope (Phalaropus fulicarius), was recorded for Santa Rosa Island. The current study adds 7 species of shorebirds to the fossil avifauna of the Channel Islands and 6 of these species to California's fossil avifauna (Miller and DeMay 1942, Jefferson 1991, Guthrie 2009). Species added to the paleoavifauna of San Miguel 
Island by the current study include Snowy Plover (Charadrius nivous), Killdeer (Charadrius vociferous), Ruddy Turnstone (Arenaria interpres), Pectoral Sandpiper (Calidris melanotus), Western Sandpiper (Calidris mauri), Spotted Sandpiper (Actitis macularius), and Wilson's Phalarope (Phalaropus tricolor). Only 3 of the 19 species of shorebirds recorded in the fossil record of San Miguel are known to currently nest on this island, with the remaining species being seasonal migrants or winter visitors, similar to their status today on the Channel Islands (Collins and Jones 2015). Of the 3 species that breed today on San Miguel (Black Oystercatcher [Haematopus bachmani], Snowy Plover, and Killdeer), Snowy Plover is the only species we confirmed to have nested prehistorically on the island. A partial, immature humerus of this species was recovered from Stratum III in Cave of the Chimneys (CA-SMI-603). A small breeding population of Snowy Plovers occurs today on the sand spit at Cardwell Point located at the east end of the island approximately $2.2 \mathrm{~km}$ (1.4 miles) southeast of Cave of the Chimneys (Page and Stenzel 1981, Page et al. 1991). Of 105 shorebird bones recovered and identified from fossil sites on San Miguel Island, $68.6 \%(n=72)$ were from owl- or falcon-generated nest/roost deposits. Identification of prey remains collected between 1988 and 2017 from 121 Peregrine Falcon eyries on the Channel Islands showed that shorebirds made up $17.9 \%$ MNI of the falcon's overall diet, with 246 individuals from at least 18 species of shorebirds recorded (P.W. Collins unpublished data). Since Peregrine Falcons are known to feed during the day and to prey regularly on shorebirds (Sherrod 1978, White et al. 2002; P.W. Collins unpublished data), whereas Barn Owls feed mostly at night on rodents and only occasionally on shorebirds (Marti 1992), it is likely that most of the shorebird remains identified from fossil sites on San Miguel and Santa Rosa Islands result from predation by Peregrine Falcons and not Barn Owls.

\section{Nonpasserine Terrestrial Birds}

Currently, the nonpasserine terrestrial paleoavifauna of the northern Channel Islands includes 17 species, with 1 vulture, 4 hawks, 3 falcons or caracaras, 2 doves or pigeons, 4 owls, and 3 woodpeckers. We added 4 species of nonpasserine land birds to the northern
Channel Islands paleoavifauna, including White-tailed Kite (Elanus leucurus); Mourning Dove (Zenaida macroura); Acorn Woodpecker (Melanerpes formicivorus); and Red-breasted Sapsucker (Sphyrapicus ruber), which is the only new species added to the fossil avifauna of California (Jefferson 1991, Guthrie 2009). Most of the nonpasserines recorded in the fossil record for the northern Channel Islands are represented by relatively few bones, while a few species that nested prehistorically, such as Bald Eagle, and several species of owls had a greater number of identified bones. Guthrie (2005) suggested that fossil remains of species like Red-tailed Hawk, Crested Caracara, and Peregrine Falcon appeared to be associated with prehistoric nest/roost sites frequented by the Bald Eagle. All of the nonpasserine land birds recorded in the fossil record from the northern Channel Islands, except for the Rancho La Brea Condor and an extinct eared owl (Asio priscus), are present today on one or more of the Channel Islands (Collins and Jones 2015). Of the 17 native species of terrestrial birds that nest today on San Miguel (Collins and Jones 2015), 5 were confirmed to have nested prehistorically on the island, including 3 species of nonpasserine land birds (Bald Eagle, Burrowing Owl, and Barn Owl). We added Barn Owl and Burrowing Owl to the list of species that nested prehistorically on San Miguel Island. For Burrowing Owls, 2 immature bones were recovered from Daisy Cave (CA-SMI-261A) and from Cave of the Chimneys (CA-SMI-603), both likely the result of Barn Owls preying on juvenile Burrowing Owls. Twenty-three immature Barn Owl bones were identified from 2 fossil deposits (SMI-V18, V-20) and 2 fossil cave/rockshelter deposits (CA-SMI-261, CA-SMI-261A), which were probably prehistoric Barn Owl nest/roost sites. Based on the provenience of these remains, Barn Owls were confirmed as nesting on San Miguel Island throughout the Holocene. An extinct species of eared owl (Asio priscus), closely related to the living Short-eared Owl (Asio flammeus) found on the mainland, is the only endemic species of nonpasserine to have disappeared in the Late Pleistocene to Early Holocene from the paleoavifauna of the northern Channel Islands. Asio priscus was characterized as having smaller wings and larger legs than the similarly sized Short-eared Owl found on the mainland (Campbell 2013). 


\section{Passerine Terrestrial Birds}

Prior published work on the paleoavifauna of San Miguel and Santa Rosa Islands resulted in the identification of only 80 bones from 5 passerine species (Orr 1968, Guthrie 1980, 2005). We increased the number of identified passerine bones to 2151 and the number of passerine species to 48 . As a result, songbirds of the order Passeriformes now compose $32.7 \%$ (48 species) of the 147 species of birds recorded in the paleoavifauna of the northern Channel Islands but only $9.6 \%$ of the total bird bone identified to date from fossil sites on San Miguel and Santa Rosa Islands. This fossil passerine avifauna resembles the passerine avifauna found today on both islands. Most of the passerine species identified in this fossil avifauna occur today on the 2 islands as either seasonal migrants (25 species) or as winter visitors (11 species), with 10 of the 12 species being resident breeders on one or both of the islands (Collins and Jones 2015).

We added 43 species of passerines to the fossil avifauna of the Channel Islands and 23 species to the fossil avifauna of California (Miller and DeMay 1942, Jefferson 1991, Guthrie 2009). Most passerine species were from 3 families, Passerellidae (12 species), Icteridae (7 species), and Turdidae (6 species), with 23 additional species recorded from 10 other passerine families. The greatest number of identified passerine bones were from Passerellidae ( 1570 bones, $73.1 \%$ NISP), Icteridae (165 bones, 7.7\% NISP), and Fringillidae (85 bones, $4.0 \%$ NISP). The majority of identified passerine bone was from ground-foraging species (New World sparrows, finches, shrikes, larks, thrushes, and thrashers), or from species that roost communally (corvids and icterids), with fewer bones identified from species that prefer to forage and roost in densely vegetated scrub and woodland habitats (wrens, waxwings, wood-warblers, cardinals, and allies) or that are diurnal aerial foragers (flycatchers). Based on these results it would appear that Barn Owls were selectively preying on groundforaging species that may have been more readily accessible than species that forage and roost in denser vegetation.

Our identification of immature passerine bone confirmed that at least 10 species of passerines nested on San Miguel Island during the Holocene, with 8 species known to nest on the island today (Collins and Jones
2015) and 2 species (Island Scrub-Jay and Spotted Towhee) new to the breeding avifauna of this island. The only other passerines known to nest today on San Miguel that were not known to nest prehistorically on this island through the identification of immature bone were Orange-crowned Warbler (Oreothlypis celata) and Lesser Goldfinch (Spinus psaltria). Twenty-four bones of 10 Orangecrowned Warblers were identified from 4 fossil sites on the island, while only a single bone of a Chipping Sparrow (Spizella passerina) was identified. There is at least one other passerine recorded in the fossil record on San Miguel that probably was nesting on this island prehistorically: Bewick's Wren. No immature bone of this species was identified during the current study, but 34 bones from at least 9 individuals were recovered and identified from 3 San Miguel Island fossil sites. Based on the amount and distribution at multiple fossil sites of identified Orangecrowned Warbler and Bewick's Wren bone, we conclude that both species probably also nested prehistorically on San Miguel Island.

We identified 5 land birds (Burrowing Owl, Black Phoebe [Sayornis nigricans], Island Scrub-Jay, Bewick's Wren, and Spotted Towhee) confirmed or suspected to have been resident breeders on San Miguel Island during the Late Pleistocene-Holocene that disappeared from the island's breeding avifauna prior to the late 1800 s, when ornithologists first began documenting the island's avifauna. All these species could easily have disbursed to San Miguel multiple times during the Pleistocene, when the island was part of the larger Santarosae landmass. Excluding Island Scrub-Jay, which is a poor overwater disburser, the other 4 species could also have reached San Miguel easily even when it was a separate island. Four of these species are known to occur today on this island as winter visitors (Burrowing Owl and Black Phoebe) or uncommon to rare transients (Bewick's Wren, Spotted Towhee; Collins and Jones 2015). All historic observations of Burrowing Owls and Black Phoebes on San Miguel Island since the late 1800s are of birds that were wintering on the island. Burrowing Owls are currently uncommon to fairly common winter visitors to all of the Channel Islands, and occasional breeders today only on Santa Barbara, Santa Catalina, and San Clemente Islands (Collins 
and Jones 2015). Black Phoebes currently nest regularly on Santa Rosa, Santa Cruz, and Santa Catalina, but only occasionally on most of the other islands (Collins and Jones 2015). There is only one recent observation of Black Phoebes nesting on San Miguel (Collins and Jones 2015). Clearly, Burrowing Owls nested on San Miguel Island prehistorically but no longer nest on the island today, while Black Phoebes nested on the island prehistorically and do so only occasionally today.

It is difficult to determine precisely when passerine species that nested prehistorically on an island like San Miguel were locally extirpated. For some species there is an incomplete fossil record due to (1) a lack of well provenienced samples from sites that span the prehistoric-to-historic transition and (2) absence of descriptions of the historic avifauna of the northern Channel Islands by ornithologists who did not visit these islands until well after terrestrial habitats had been dramatically altered by severe drought and vegetation stripping by herbivores introduced to the island in 1851. As a result, there are no historic observations or collected specimens for passerines that nested on San Miguel Island prehistorically that can be used to confirm whether a species went extinct during the historic period as a result of habitat changes prior to the arrival of Europeans with their livestock.

The Island Scrub-Jay, which today is restricted to Santa Cruz Island, is the only endemic full species of bird found on the Channel Islands. Genetic evidence determined that the Island Scrub-Jay diverged from the Western Scrub-Jay (Aphelocoma californica) at least 100,000 years ago with no further colonization from the mainland (Delaney and Wayne 2005). This timing would have allowed Island Scrub-Jays from Santa Cruz Island to colonize the larger Santarosae landmass via overland dispersal a number of times during the Pleistocene, when sea levels dropped sufficiently to connect all the northern Channel Islands. Ornithologists have assumed that this species disappeared from Santa Rosa Island in prehistoric times (Curry and Delaney 2002, Delaney and Wayne 2005), but evidence of this wider distribution was lacking until our study. We found bones of this species from a series of fossil sites on San Miguel and Santa Rosa Islands, confirming that the Island Scrub-Jay had a wider distribution on the northern Channel Islands in the past. One of the challenges of determining when Island Scrub-Jays went extinct on each of these islands is that relatively few bones referable to this species have been recovered from welldated assemblages. For Santa Rosa Island, there is only a single Island Scrub-Jay bone recovered from a geologic formation which Orr (1968) listed as being of Late Pleistocene age but which lacks any direct ${ }^{14} \mathrm{C}$ dates that more precisely date this specimen. For San Miguel, 5 of the 14 Island Scrub-Jay bones recovered from Daisy Cave are associated with precise ${ }^{14} \mathrm{C}$ dates ranging from $\sim 12,400$ cal BP to 8400 cal BP. This species may have disappeared from San Miguel Island during the Middle to Late Holocene as climate warmed and as island vegetation communities changed from conifer woodlands of the Pleistocene to drier scrublands and grasslands of the Holocene and historic period. More precise dating of the other Island Scrub-Jay bones of trans-Holocene age might determine how long this species persisted on San Miguel Island following its last separation from Santa Rosa Island 9.4 to $9.1 \mathrm{ka}$ ago, and if a population of jays could have lingered on San Miguel into the historic period before going extinct. Suitable woodland habitat for jays on San Miguel Island declined during the Pleistocene, and the size of the island decreased as sea levels rose following the LGM. These factors would have led to reductions in any jay population that remained on San Miguel during the Holocene, making it susceptible to increased risks of extinction from vulnerabilities that are known to plague small, isolated populations. On Santa Rosa Island it is less clear when Island Scrub-Jays went extinct. The fossil record currently provides no data useful for determining when the species disappeared from Santa Rosa's breeding avifauna. Field notes from Clark P. Streator, an ornithologist who collected birds on Santa Rosa Island for the Smithsonian Institution in 1892, state that "Mr. John Moore informs me that there are jays on the island" (Collins 2009, Morrison et al. 2011). This suggests that a small population of Island Scrub-Jays may have survived on Santa Rosa Island into historic times and that this population went extinct toward the end of the $1800 \mathrm{~s}$ when more than 80,000 to 100,000 sheep were decimating island vegetation communities. Island Scrub-Jays clearly 
were distributed across the Santarosae landmass during the Pleistocene and into the Holocene. Environmental change since the end of the Pleistocene coupled with habitat changes resulting from drought and heavy grazing likely contributed to the extinction of this species on at least Santa Rosa Island.

Two other passerines (Bewick's Wren and Spotted Towhee) resident on San Miguel Island during the Holocene may have disappeared from the island during the latter half of the 19th century as a result of destruction of their preferred scrub habitats from herbivore grazing. Identification of 34 Bewick's Wren bones (9 MNI) from 3 Holocene-aged sites on San Miguel may represent a resident species that nested prehistorically on the island. Bones from this species were recovered from Stratum II through VII at Cave of the Chimneys, dating between $\sim 8030$ and $2190 \mathrm{cal} \mathrm{BP}$. We identified no immature bones of this species, nor were any bones found in strata dated closer to the present; however, Bewick's Wrens were probably resident in dense coastal scrub habitats found on San Miguel during the Holocene and into the historic period. If a resident population of the species was still present on the island into the 19th century, loss of dense scrub cover to herbivore grazing almost certainly led to its extinction. Bewick's Wrens today are rare spring and occasional fall transients on San Miguel, Santa Barbara, and San Nicolas Islands, where the species currently does not nest (Collins and Jones 2015). If the prehistoric status of this species on San Miguel was similar to its current rare seasonal status on the island today, then Bewick's Wrens would not have been as readily available as prey for Barn Owls and should be much less common in the avian fossil record from this island than our study recorded. Also, since this species currently nests on Santa Rosa, Santa Cruz, and Anacapa Islands, it seems likely that it would have been resident on San Miguel when this island was part of Santarosae. Scrublands, which were common on San Miguel Island throughout the Holocene and into the historic period, would have provided suitable breeding habitat for this species. Today, Bewick's Wrens nest on Santa Rosa, Santa Cruz, Anacapa, and Santa Catalina Islands (Collins and Jones 2015). They also nested on Guadalupe Island off the coast of central Baja California until the late 1800s (Anthony 1901, Thayer and Bangs 1908) and on San Clemente Island until the 1960s (Sullivan and Kershner 2005), when destruction of scrub habitat by feral goats (Capra hircus) and increased predation by feral cats (Felis catus) resulted in their extinction from both islands. The species was also reported by Cooper (1870) as present on San Nicolas and Santa Barbara Islands in the early 1860s, but until recently a lack of any subsequent observations or collected specimens from either island suggested that his findings were suspect. The recent recovery of Bewick's Wren bones from column samples excavated from Barn Owl Cave on Santa Barbara Island (P.W. Collins unpublished data) lends credence to Cooper's finding that this species was probably present on this island in the 1860s. If Bewick's Wrens were present during the historic period on one or both of these islands, then destruction of scrub habitats following the introduction of herbivores in the mid-1800s could have led to the species' local extirpation before ornithologists began documenting the avifauna of these 2 islands. We conclude that Bewick's Wrens were probably resident on San Miguel, Santa Barbara, and San Nicolas Islands historically but were locally extirpated by the late 1800 s as a result of destruction of their preferred scrub breeding habitat from overgrazing by introduced herbivores.

The final passerine that may have gone extinct on San Miguel Island since the end of the Holocene is the Spotted Towhee. This species occurs today as a resident breeder on Santa Rosa, Santa Cruz, and Santa Catalina (Collins and Jones 2015), and occurred until the mid-1970s on San Clemente (Sullivan and Kershner 2005). On the islands where the Spotted Towhee currently does not nest, it occurs as a rare to fairly common spring and fall transient, and it is an occasional transient on San Miguel Island Collins and Jones 2015) with no evidence that it nested there historically. On the islands where this species has been recorded breeding, it prefers dense chaparral and woodlands (oak, pine, and riparian) that contain a well-developed understory cover of shrubs which overhang a dense surface layer of leaf litter and humus (Grinnell and Miller 1944, Collins 2008). This species prefers to nest on or near the ground in dense, low-growing shrubs (Greenlaw 1996). Spotted Towhees associate with thicket-forming plants 
such as coyote bush (Baccharis pilularis), coastal sagebrush (Artemisia californica), toyon (Heteromeles arbutifolia), chamise (Adenostoma fasciculatum), manzanita (Arctostaphylos), sumac (Rhus), ceanothus (Ceanothus), and saltbush (Atriplex) (Greenlaw 1996). Many of these thicket-forming shrub species occur today on the larger islands where Spotted Towhees currently reside, and on San Miguel Island some also occur today and a few may have occurred prehistorically.

A total of 367 Spotted Towhee bones from at least 70 individuals were identified from 4 San Miguel Island sites of Holocene age and from one fossil site (SRI-V-2) of Late Pleistocene age on Santa Rosa Island. Bones of this species were recovered from at least 3 welldated assemblages on San Miguel Island. Seventy bones from 11 individuals were recovered from SMI-V-20, a $\sim 7300$-year-old Barn Owl roost. Nine Spotted Towhee bones were recovered from Strata A through E at Daisy Cave (CA-SMI-261), dating from as early as $\sim 8500-9250$ cal BP to as recent as $\sim 2850-3700$ cal BP (Appendix 1). At Cave of the Chimneys (CA-SMI-603), 172 Spotted Towhee bones were recovered from 7 strata spanning most of the Holocene with the species recorded as early as $8030 \mathrm{cal} \mathrm{BP}$ (Stratum VII) and as recent as $960 \mathrm{cal}$ BP (Stratum I). Spotted Towhees were also confirmed to breed prehistorically on San Miguel Island based on the identification of 4 immature bones, 1 from SMI-V-20 and 3 from CA-SMI-603. The fossil record for the occurrence of this species on San Miguel Island to at least $960 \mathrm{cal}$ BP suggests that it was probably present on the island into the historic period. However, we know of no observations or collected specimens of this species from San Miguel Island during the 1800 s or early 1900 s suggesting that the species was present historically. This is not surprising, as ornithologists did not begin to study the avifauna of San Miguel Island until 1886 and 1892 , by which time scrub habitats had been largely destroyed by overgrazing, which could have resulted in the extinction of a resident breeding population. The Spotted Towhee was extirpated in historic times (ca. 1897) on Guadalupe Island due to destruction of its preferred scrub breeding habitat by feral goats and increased predation by feral cats (Anthony 1901, Thayer and Bangs 1908, Howell and Cade 1954, Barton et al. 2004).
The species was also extirpated from San Clemente Island shortly after being observed for the last time on the island in July 1975, due principally to destruction of scrub and woodland habitats by feral goats coupled with increased predation from feral cats (Jones and Diamond 1976, Jorgensen and Ferguson 1984, Sullivan and Kershner 2005, Collins 2008). Given that the species was extirpated on at least 2 other California Islands as a result of loss of dense scrub habitats, and that bones of this species were found in a series of San Miguel Island sites spanning the Holocene, Spotted Towhees were probably resident on San Miguel into historic times before being driven to extinction as a result of habitat destruction by introduced herbivores.

\section{SumMARY AND CONCLUSIONS}

Previous studies of the fossil avifauna of San Miguel and Santa Rosa Islands focused principally on identification of larger-sized and more intact bird bone, leaving fragmented and smaller shorebird, marine bird, passerine, and nonpasserine bone unidentified. We report here the reevaluation and identification of previously unidentified avian remains from 29 fossil sites on San Miguel and Santa Rosa Islands, as well as avian remains recovered from trans-Holocene deposits excavated from Cave of the Chimneys (CA-SMI-603), Daisy Cave (CA-SMI-261, Column E-6), and Cave A (CA-SMI-261A). Identification of previously unidentified and more recently collected bird bone has increased the fossil avifauna of San Miguel and Santa Rosa Islands from 83 to 147 species, with 62 species added to the San Miguel avifauna and 16 species added to the Santa Rosa avifauna. The majority of species added to the fossil avifauna of these 2 islands were from the orders Passeriformes (41 species) and Charadriiformes (11 species). Through the careful study of small avian bones recovered from fossil sites on the northern Channel Islands, it was possible to describe for the first time the fossil terrestrial passerine avifauna that was present on San Miguel Island from the Late Pleistocene through the Holocene. This fossil passerine avifauna comprised 48 species from 13 families, with most species being common transients or winter visitors on the Channel Islands today. Based on the identification of juvenile/immature bone, a total 
of 22 species nested on San Miguel Island during the Holocene. This prehistoric breeding avifauna was comprised of 9 species of seabirds, 1 shorebird, 2 nonpasserines, and 10 passerines. By describing the prehistoric passerine fauna of these 2 islands, it was possible to identify species that probably persisted into the historic era before being extirpated as a result of anthropogenic effects resulting from the introduction of herbivores to the northern Channel Islands. At least 5 species of birds (Black-vented Shearwater, Burrowing Owl, Island Scrub-Jay, Bewick's Wren, and Spotted Towhee) that nested prehistorically on San Miguel Island appear to have disappeared from the breeding avifauna found on the island today. Three passerines disappeared as breeders from San Miguel Island, either during the mid- to Late Holocene for Island Scrub-Jays or during the latter half of the 19th century for Bewick's Wren and Spotted Towhee. A small remnant population of Island Scrub-Jays may also have persisted on Santa Rosa Island into the late 19th century before being driven extinct. Destruction of scrub and woodland habitats on both of these islands from overgrazing by introduced herbivores is the principal factor that led to the extinction of resident populations of these species on San Miguel Island (Bewick's Wren and Spotted Towhee) and on Santa Rosa Island (Island Scrub-Jay) by the end of the 19th century.

\section{ACKNOWLEDGMENTS}

We thank Kimball Garrett for providing access to comparative avian skeletons in the ornithology collection at the Natural History Museum of Los Angeles County, Alexis Mychajliw for preparing Figs. 1 and 2, and Amira Ainis for review and editorial suggestions for ${ }^{14} \mathrm{C}$ dates listed in Appendix 1 and for comments that helped to improve the manuscript. This manuscript also benefitted greatly from the comments of 2 anonymous reviewers, Torben Rick, and the associate editor Mike Glassow.

\section{Literature Cited}

AINIS, A.F. 2012. Eight thousand years at Bay Point: archaeology and historical ecology at Cave of the Chimneys (CA-SMI-603), San Miguel Island, California. Master's thesis, Department of Anthropology, California State University, Los Angeles, CA.

Ainis, A.F., AND R.L. VELLANOWETH. 2012. Expanding the chronology for the extinct giant island deer mouse
(Peromyscus nesodytes) on San Miguel Island, California, USA. Journal of Island and Coastal Archaeology 7:146-152.

Ainis, A.F., R.L. Vellanoweth, T.W. Davis, J.M. ErLandSON, AND T.C. RICK. 2011. Changes in marine subsistence on San Miguel Island from 8,500 to 2,400 years ago: analysis of bulk samples from Cave of the Chimneys (CA-SMI-603). Journal of California Great Basin Anthropology 31:59-79.

Ainis, A.F., R.L. Vellanoweth, Q.G. Lapena, and C.S. THORNBER. 2014. Using non-dietary gastropods in coastal shell middens to infer kelp and seagrass harvesting and paleoenvironmental conditions. Journal of Archaeological Science 49:343-360.

Allen, J.A. 2013. Non-cultural deposition in an archaeological site: microfaunal remains from Cave of the Chimneys (CA-SMI-603), San Miguel Island, California. Master's thesis, Department of Anthropology, California State University, Los Angeles, CA.

[AOU] AMERICAN OrNithologists' Union. 1957. Checklist of North American Birds. American Ornithologists' Union, Baltimore, MD.

[AOU] American Ornithologists' Union. 1998. Checklist of North American Birds. 7th edition. American Ornithologists' Union, Washington, DC.

Anderson, R.L., R. Byrne, and T. Dawson. 2008. Stable isotope evidence for a foggy climate on Santa Cruz Island, California at 16,600 cal. yr. B.P. Palaeogeography, Palaeoclimatology, Palaeoecology 262:176-181.

Anderson, R.S., A. Ejarque, J. Rice, S.J. Smith, and C.G. LeBow. 2015. Historic and Holocene environmental change in the San Antonio Creek Basin, midcoastal California. Quaternary Research 83:273-286.

Anderson, R.S., S. Starkatt, R.M.B. Jass, and N. Pinter. 2010. Fire and vegetation history on Santa Rosa Island, Channel Islands, and long-term environmental change in southern California. Journal of Quaternary Science 25:782-797.

Anthony, A.W. 1901. The Guadalupe Wren. Condor 3:73. Barton, D.C., K.E. Lindquist, R.W. Henry, and L.M.L. MENDOZA. 2004. Landbird and waterbird notes from Isla Guadalupe, Mexico. Western Birds 35:186-196.

Brodkorb, P. 1978. Catalogue of fossil birds, part 5 (Passeriformes). Bulletin of the Florida State Museum, Biological Sciences 23:139-228.

Campbell, K.E., JR. 2013. Revisiting Asio priscus, an extinct eared owl of the California Channel Islands. Pages 185-194 in U.B. Göhlich and A. Kroh, editors, Proceedings 8th International Meeting of the Society of Avian Paleontology and Evolution. Paleornithological Research 2013. Verlag Naturhistorisches Museum, Wien, Österreich.

Carter, H.R., G.J. McChesney, D.L. Jaques, C.S. Strong, M.W. Parker, J.E. Takekawa, D.L. Jory, AND D.L.WhitworTH. 1992. Breeding populations of seabirds in California, 1989-1991. Volume 1, Population estimates. Unpublished draft final report, U.S. Fish and Wildlife Service, Northern Prairie Wildlife Research Center, Dixon, CA.

Carter, H.R., D.L. Whitworth, P.N. Hebert, J.S. Koepke, P.J. Capitolo, G.J. McChesney, W.R. McIver, L.K. Ochikubo Chan, M.O. Pierson, A. Hebshi, and P. Martin. 2008. Status of breeding seabirds in the San Miguel Island group, California. Unpublished report, Carter Biological Consulting, Victoria, British Columbia, and California Institute of Environmental Studies, Davis, CA. 
Chaney, R.W., and H.L. Mason. 1930. A Pleistocene flora from Santa Cruz Island, California. Carnegie Institute of Washington Publication 415:1-24.

Chesser, R.T., K.J. Burns, C. Cicero, J.L. Dunn, A.W. Kratter, I.J. Lovette, P.C. Rasmussen, J.V. RemSEN JR., J.D. Rising, D.F. STOTZ, AND K. Winkler. 2017. Fifty-eighth supplement to the American Ornithological Society's Check-list of North American Birds. Auk 134:751-773.

Clark, J., J.X. Mitrovica, and J. Alder. 2014. Coastal paleogeography of the California-Oregon-Washington and Bering Sea continental shelves during the latest Pleistocene and Holocene: implications for the archaeological record. Journal of Archaeological Science 52:12-23.

Cole, K.L., AND G. LiU. 1994. Holocene paleoecology of an estuary on Santa Rosa Island, California. Quaternary Research 41:326-335.

Collins, P.W. 2008. San Clemente Spotted Towhee (Pipilo maculatus clementae). Pages 365-370 in W.D. Shuford and T. Gardali, editors, California bird species of special concern: a ranked assessment of species, subspecies, and distinct populations of birds of intermediate conservation concern in California. Studies of Western Birds 1. Western Field Ornithologists, Camarillo, CA, and California Department of Fish and Game, Sacramento, CA.

Collins, P.W. 2009. Historic and prehistoric record for the occurrence of Island Scrub-Jays (Aphelocoma inularis) on the northern Channel Islands, Santa Barbara County, California. Santa Barbara Museum of Natural History, Technical Report No. 5.

Collins, P.W., D.A. Guthrie, T.C. Rick, and J.M. ERLANDSON. 2005. Analysis of prey remains excavated from an historic Bald Eagle nest site on San Miguel Island, California. Pages 103-120 in D.K. Garcelon and C.A. Schwemm, editors, Proceedings of the Sixth California Islands Symposium. National Park Service Technical Publication CHIS-05-01, Institute for Wildlife Studies, Arcata, CA.

COLLins, P.W., AND H.L. JONES. 2015. A checklist of birds of the California Channel Islands. Santa Barbara Museum of Natural History, Santa Barbara, CA.

Cooper, J.G. 1870. The fauna of California and its geographical distribution. Proceedings of the California Academy of Sciences No. 4:61-81.

Curry, R.L., AND K.S. Delaney. 2002. Island Scrub-Jay (Aphelocoma insularis). In: A. Poole and F. Gill, editors, The Birds of North America, No. 713. The Birds of North America, Inc., Philadelphia, PA.

DELaney, K.S., AND R.K. Wayne. 2005. Adaptive units for conservation: population distinction and historic extinctions in the Island Scrub-Jay. Conservation Biology 19:523-533.

Emslie, S.D. 1988. The fossil history and phylogenetic relationships of condors (Ciconiiformes: Vulturidae) in the New World. Journal of Vertebrate Paleontology 8:212-228.

Erlandson, J.M., D.J. KennetT, B.L. Ingram, D.A. Guthrie, D.P. Morris, M.A. Tveskov, G.J. West, And P.L. WALKER. 1996. An archaeological and paleontological chronology for Daisy Cave (CA-SMI-261), San Miguel Island, California. Radiocarbon 38:355-373.

Erlandson, J.M., M.L. Moss, and M. Des Lauriers. 2008. Life on the edge: early maritime cultures of the Pacific Coast of North America. Quaternary Science Reviews 27:2232-2245.
Erlandson, J.M., T.C. Rick, T.J. Braje, M. Casperson, B. Culleton, B. Fulfrost, T. Garcia, D.A. Guthrie, N. Jew, D.J. Kennett, et AL. 2011. Paleocoastal seafaring, maritime technologies, and coastal foraging on California's Channel Islands. Science 331: $1181-1185$.

Everett, W.T. 1988. Biology of the Black-vented Shearwater. Western Birds 19:89-104.

Gilbert, B.M., L.D. Martin, and H.G. Savage. 1996. Avian osteology. Missouri Archaeological Society, Inc.

Greenlaw, J.S. 1996. Spotted Towhee (Pipilo maculatus). No. 263 in A. Poole and F. Gill, editors, The Birds of North America. The Birds of North America, Inc., Philadelphia, PA.

Grinnell, J., AND A.H. Miller. 1944. The distribution of the birds of California. Pacific Coast Avifauna No. 27.

Guthrie, D.A. 1980. Analysis of avifaunal and bat remains from midden sites on San Miguel Island. Pages 689-702 in D.M. Power, editor, The California Channel Islands: proceedings of a multidisciplinary symposium. Santa Barbara Museum of Natural History, Santa Barbara, CA.

Guthrie, D.A. 1985. Reconnaissance of Quaternary Deposits near Frenchy's Cove, Anacapa Island Preliminary Report on 1985 Activities Amended Permit P949-CA-84. Report on file at Channel Islands National Park, Ventura, CA.

Guthrie, D.A. 1992a. Fossil localities for Santa Rosa Island. Unpublished report submitted to Channel Islands National Park dated 13 February 1992. Copy on file at Channel Islands National Park, Ventura, CA. 7 pp.

Guthrie, D.A. 1992b. A late Pleistocene avifauna from San Miguel Island, California. Pages 320-327 in K.E. Campbell, editor, Papers on Avian Paleontology, Los Angeles, CA. Natural History Museum of Los Angeles County Science Series, Los Angeles, CA.

Guthrie, D.A. 1993. New information on the prehistoric fauna of San Miguel Island, California. Pages 405-416 in F.G. Hochberg, editor, Third Channel Islands Symposium: recent advances in research on the California Islands. Santa Barbara Museum of Natural History, Santa Barbara, CA.

Guthrie, D.A. 1998. Fossil vertebrates from Pleistocene terrestrial deposits on the northern Channel Islands, Southern California. Pages 187-192 in P.W. Weigand, editor, Contributions to the geology of the northern Channel Islands, Southern California. MP 45. American Association of Petroleum Geologists, Pacific Section, Bakersfield, CA.

Guthrie, D.A. 2005. Distribution and provenance of fossil avifauna on San Miguel Island. Pages 35-42 in D.K. Garcelon and C.A. Schwemm, editors, Proceedings of the Sixth California Islands Symposium. National Park Service Technical Publication CHISOS-01, Institute for Wildlife Studies, Arcata, CA.

Guthrie, D.A. 2009. An updated catalogue of the birds from the Carpinteria asphalt Pleistocene of California. Bulletin of the Southern California Academy of Sciences 108(2):52-62.

Guthrie, D.A., H.W. Howell, AND G.L. Kennedy. 2002. A new species of extinct Late Pleistocene puffin (Aves: Alcidae) from the southern California Channel Islands. Pages 525-530 in D.R. Brown, K.L. Mitchell, and H.W. Chaney, editors, Proceedings of 
the Fifth California Islands Symposium, Camarillo, California. Minerals Management Service, Pacific OCS Region, OCS Study MMS-99-38.

Hamon, J.H. 1964. Osteology and paleontology of the passerine birds of the Reddick, Florida, Pleistocene. Florida Geological Survey, Geological Bulletin No. 44.

Hardiman, M., A.C. Scott, N. Pinter, R.S. Anderson, A. Ejarque, A. Carter-Champion, and R.A. Staff. 2016. Fire history on the California Channel Islands spanning human arrival in the Americas. Philosophical Transactions Royal Society B 371:20150167.

Heusser, L.E. 1978. Pollen in Santa Barbara Basin, California: a 12,000-yr record. Geological Society of America Bulletin 89:673-678.

Heusser, L.E. 1995. Pollen stratigraphy and paleoecological interpretation of the 160-k.y. record from Santa Barbara Basin, Hole 893A. Pages 265-279 in J.P. Kennett, J.G. Baldauf, and M. Lyle, editors, Proceedings of the Ocean Drilling Program, Scientific Results, Vol. 146. Ocean Drilling Program, College Station, TX.

Heusser, L.E. 1998. Direct correlation of millennialscale changes in western North American vegetation and climate with changes in the California Current System over the past 60 kya. Paleoceanography 13:252-262.

Howard, H. 1929. The avifauna of Emeryville shell mound. University of California Publications in Zoology 32:301-394.

HowarD, H. 1938. The Rancho La Brea Caracara: a new species. Contributions to Palaeontology, Carnegie Institute of Washington 487:217-240.

HowarD, H. 1944. Miscellaneous avian fossil records from California. Bulletin of the Southern California Academy of Sciences 43:74-77.

Howard, H. 1949. Avian fossils from the marine Pleistocene of Southern California. Condor 51:20-28.

Howard, H. 1955. New records and a new species of Chendytes, an extinct genus of diving geese. Condor 57:135-143.

Howard, H. 1962. A fossil bird, Caracara, from Santa Rosa Island. Bulletin of the Southern California Academy of Sciences 61:227-228.

Howard, H. 1964a. A fossil owl from Santa Rosa Island, California. Bulletin of the Southern California Academy of Science 63:27-31.

Howard, H. 1964b. Further discoveries concerning the flightless "Diving Geese: of the Genus Chendytes." Condor 66:372-376.

Howell, T.R., and T.J. Cade. 1954. The birds of Guadalupe Island in 1953. Condor 56:283-294.

JEFFERSON, J.T. 1991. A catalogue of Late Quaternary vertebrates from California: part one, nonmarine lower vertebrate and avian taxa. Natural History Museum of Los Angeles County Technical Reports No. 5.

Johnson, D.L. 1972. Landscape evolution on San Miguel Island, California. Doctoral dissertation, University of Kansas, Lawrence, KS.

Johnson, D.L. 1977. The Late Quaternary climate of coastal California: evidence for an ice-age refugium. Quaternary Research 8:154-179.

Jones, H.L., AND J.M. Diamond. 1976. Short-time-base studies of turnover in breeding bird populations on the California Channel Islands. Condor 78:526-549.

Jorgensen, P.D., AND H.L. Ferguson. 1984. The birds of San Clemente Island. Western Birds 15:111-130.
Junak, S., T. Ayers, R. Scott, D. Wilken, and D. Young. 1995. A flora of Santa Cruz Island. Santa Barbara Botanic Garden, Santa Barbara, CA.

KeItT, B.S., B.R. Tershey, And D.R. Croll. 2000. Blackvented Shearwater (Puffinus opisthomelas). No. 521 in A. Poole and F. Gill, editors, The Birds of North America. The Birds of North America, Inc., Philadelphia, PA.

Kennett, D.J., J.P. Kennett, G.L. West, J.M. Erlandson, J.R. Johnson, I.L. Hendy, A. West, B.J. CulLeton, T.L. Jones, and T.W. Stafford Jr. 2008. Wildfire and abrupt ecosystem disruption on California's northern Channel Islands at the AllerødYounger Dryas boundary (13.0-12.9 ka). Quaternary Science Reviews 27:2530-2545.

LippS, J.H. 1964. Late Pleistocene history of West Anacapa Island, California. Geological Society of America Bulletin 75(11):1169-1176.

Lipps, J.H., J.W. Valentine, and E. Mitchell. 1968. Pleistocene paleoecology and biostratigraphy, Santa Barbara Island, California. Journal of Paleontology 42:291-307.

Marti, C.D. 1992. Barn Owl (Tyto alba). No. 1 in A. Poole, P. Stettenheim, and F. Gill, editors, The Birds of North America. The Birds of North America, Inc., Philadelphia, PA.

McEachern, K., T. Atwater, P.W. Collins, K. FaulkNER, AND D.V. Richards. 2016. Managed island ecosystems. Pages 755-778 in H. Mooney and E. Zavaleta, editors, Ecosystems of California. University of California Press, Oakland, CA.

Mead, J.I., J. Wilkins, and P.W. Collins. 2018. Late Quaternary chorus frog (Pseudacris) from the Channel Islands, California. Bulletin, Southern California Academy of Sciences 117:52-63.

Miller, A.H. 1929. The passerine remains from Rancho La Brea in the paleontological collections of the University of California. University of California Publications Bulletin of the Department of Geological Sciences 19:1-22.

Miller, A.H. 1932. The fossil passerine birds from the Pleistocene of Carpinteria, California. University of California Publications Bulletin of the Department of Geological Sciences 21(7):169-194.

Miller, L. 1925. The birds of Rancho la Brea. Carnegie Institution of Washington Publication 349:63-106.

Miller, L., AND I. DeMay. 1942. The fossil birds of California, an avifauna and bibliography with annotations. University of California Publications in Zoology 47(4):47-142.

MilleR, L., E.D. Mitchell, AND J.H. Lipps. 1961. New light on the flightless goose Chendytes lawi. Los Angeles County Museum Contributions in Science 43:1-11.

Morrison, S.A., T.S. Sillett, C.K. Ghalambor, J.W. Fitzpatrick, D.M. Graber, V.J. Bakker, R. Bowman, C.T. Collins, P.W. Collins, K.S. Delaney, et AL. 2011. Proactive conservation management of an island-endemic bird species in the face of global change. BioScience 61:1013-1021.

Muhs, D.R., K.R. Simmons, L.T. Groves, J.P. McGeehin, R.R. Schumann, and L.D. Agenbroad. 2015. Late Quaternary sea-level history and the antiquity of mammoths (Mammuthus exilis and Mammuthus columbi), Channel Islands National Park, California, USA. Quaternary Research 83:502-521. 
Muhs, D.R., K.R. Simmons, R.R. Schumann, L.T. Groves, S.B. DeVogel, S.A. Minor, and D. Laurel. 2014 Coastal tectonics on the eastern margin of the Pacific Rim: Late Quaternary sea-level history and uplift rates, Channel Islands National Park, California, USA. Quaternary Science Reviews 105:209-238.

Muhs, D.R., G. SkipP, R.R. Shumann, D.L. Johnson, J.P. McGeehin, J. Beann, J. Freeman, T.A. Pierce, and Z.M. ROWLAND. 2009. The origin and paleoclimatic significance of carbonate sand dunes deposited on the California Channel Islands during the last glacial period. Pages 3-14 in C.C. Damiami and D.K. Garcelon, editors, Proceedings of the 7th California Islands Symposium. Institute for Wildlife Studies, Arcata, CA.

ORR, P.C. 1956. Radiocarbon dates from Santa Rosa Island, I: Santa Barbara Museum of Natural History, Department of Anthropology Bulletin No. 2:1-9.

ORR, P.C. 1960. Late Pleistocene marine terraces on Santa Rosa Island, California. Bulletin of the Geological Society of America 71:1113-1120.

ORR, P.C. 1968. Prehistory of Santa Rosa Island. Santa Barbara Museum of Natural History, Santa Barbara, CA.

Page, G.W., And L.E. Stenzel. 1981. The breeding status of the Snowy Plover in California. Western Birds $12: 1-40$.

Page, G.W., L.E. Stenzel, W.D. Shuford, and C.R. BRUCE. 1991. Distribution and abundance of the Snowy Plover on its western North American breeding grounds. Journal of Field Ornithology 62: $245-255$.

Reeder-Myers, L., J.M. Erlandson, D.R. Muhs, and T.C. Rick. 2015. Sea level, paleogeography, and archaeology on California's Northern Channel Islands. Quaternary Research 83:263-272.

REDDY, S.N., AND J.M. ERLANDSON. 2012. Macrobotanical food remains from a trans-Holocene sequence at Daisy Cave (CA-SMI-261), San Miguel Island, California. Journal of Archaeological Science 39:33-40.

Rick, T.C., J.M. ERLandson, and R.L. Vellanoweth. 2001. Paleocoastal marine fishing on the Pacific Coast of the Americas: perspectives from Daisy Cave, California. American Antiquity 66:595-613.

Rick, T.C., J.M. Erlandson, R.L. Vellanoweth, T.J. Braje, P.W. Collins, D.A. Guthrie, and T.W. StAFFord JR. 2009. Origins and antiquity of the island fox (Urocyon littoralis) on California's Channel Islands. Quaternary Research 71(2009):93-98.

Rick, T.C., C.A. Hofman, T.J. Braje, J.E. Maldonado, T.S. Sillett, K. Danchisko, and J.M. Erlandson. 2012. Flightless ducks, giant mice and pygmy mammoths: Late Quaternary extinctions on California's Channel Islands. World Archaeology 44(1):3-20.

Rick, T.C., T.S. Sillett, C.K. Ghalambor, C.A. Hofman, K. Ralls, R.S. Anderson, C.L. Boser, T.J. Braje, D.R. Cayan, R.T. Chesser, et AL. 2014. Ecological change on California's Channel Islands from the Pleistocene to Anthropocene. BioScience 64(8): 680-692.

Rozaire, C.E. 1978. Archaeological investigations on San Miguel Island, California. Los Angeles County Museum of Natural History, Los Angeles, CA.
Serjeanston, D. 2009. Birds. Cambridge University Press, Cambridge, England.

Sherrod, S.K. 1978. Diets of North American Falconiformes. Raptor Research 12:49-121.

Stott, L., C. Poulsen, S. Lund, And R. Thunell. 2002. Super ENSO and global climate oscillations at millennial time scales. Science 297:222-226.

Stuiver, M., And P.J. Reimer. 2000. Calib 4.3 Radiocarbon Calibration Program 2000. Quaternary Isotope Lab, University of Washington, Seattle, WA.

Sullivan, B.L., and E.L. Kershner. 2005. The birds of San Clemente Island. Western Birds 36:158-273.

Syverson, V.J., And D.R. Prothero. 2010. Evolutionary patterns in Late Quaternary California Condors. PalArch's Journal of Vertebrate Palaeontology 7(1): $1-18$.

ThaYer, J.E., AND O. Bangs. 1908. The present state of the ornis of Guadaloupe [sic.] Island. Condor 10: 101-106.

Vellanoweth, R.L., M.R. Lambright, J.M. Erlandson, AND T.C. RICK. 2003. Early New World maritime technologies: sea grass cordage, shell beads, and a bone tool from Cave of the Chimneys, San Miguel Island, California, USA. Journal of Archaeological Science 30(2003):1161-1173.

Vellanoweth, R.L., T.C. Rick, and J.M. Erlandson. 2002. Middle and Late Holocene maritime adaptations on northeastern San Miguel Island, California. Pages 607-614 in D.R. Brown, K.L. Mitchell, and H.W. Chaney, editors, Proceedings of the Fifth California Islands Symposium, Camarillo, California. Minerals Management Service, Pacific OCS Region, OCS Study MMS-99-38.

von den Driesch, A., D. Kessler, F. Steinmann, V. Berteaux, and J. Peters. 2005. Mummified, deified and buried at Hermopolis - the sacred birds from Tuna el-Gebel, Middle Egypt. Ägypten und Levante/ Egypt and the Levant 15:203-244.

WALKER, P. 1980. Archaeological evidence for the recent extinction of three terrestrial mammals on San Miguel Island. Pages 703-717 in D.M. Power, editor, The California Channel Islands: proceedings of a multidisciplinary symposium. Santa Barbara Museum of Natural History, Santa Barbara, CA.

West, G.J., And J.M. Erlandson. 1994. A Late Pleistocene pollen record from San Miguel Island, California: preliminary results [abstract]. Program and Abstracts: 13th Biennial Meeting. American Quaternary Association, Minneapolis, MN. Page 256.

White, C.M., N.J. Clum, T.J. Cade, and W.G. Hunt. 2002. Peregrine Falcon (Falco peregrinus). No. 660 in A. Poole and F. Gill, editors, The Birds of North America. The Birds of North America, Inc., Philadelphia, PA.

Received 28 February 2017

Revised 13 December 2017

Accepted 26 January 2018

Published online 16 October 2018 


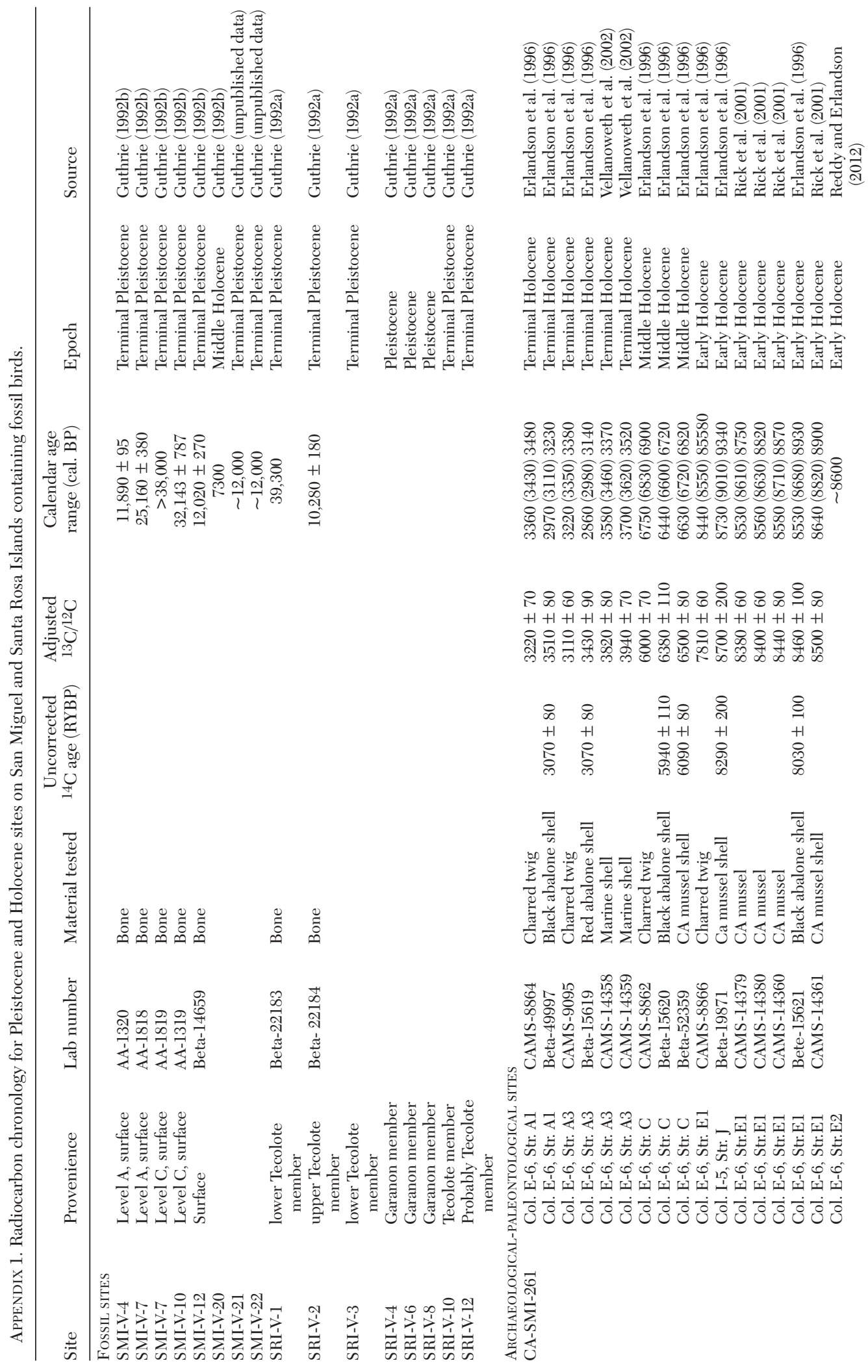




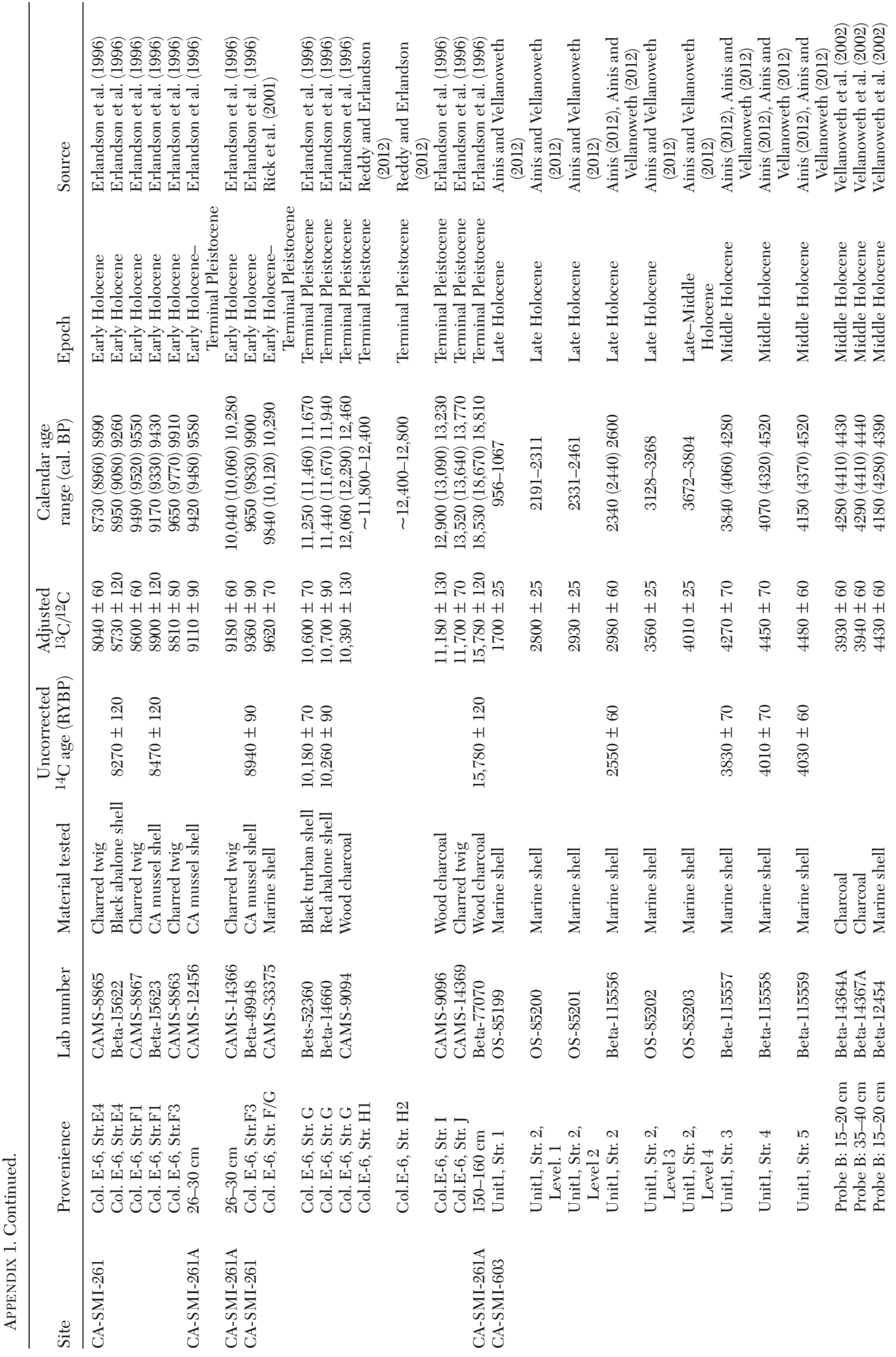




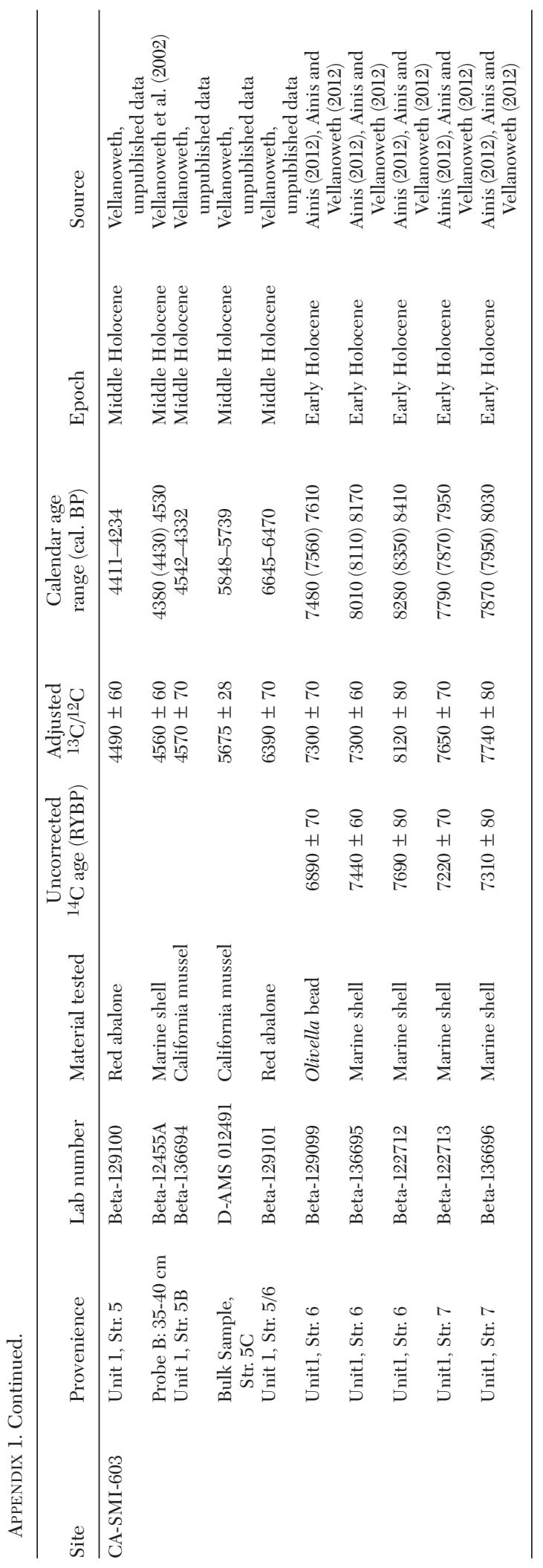

